\title{
The azide-alkyne cycloaddition catalysed by transition metal oxide nanoparticles
}

Giorgio Molteni, ${ }^{\text {a* }}$ Anna M. Ferretti, ${ }^{\mathrm{b}}$ Mario Italo Trioni, ${ }^{\mathrm{c}}$ Fausto Cargnoni, ${ }^{\mathrm{c}}$ Alessandro Ponti ${ }^{\mathrm{b} *}$

a Dipartimento di Chimica, Università degli Studi di Milano, via C. Golgi 19, 20133 Milano, Italy.

b Laboratorio di Nanotecnologie, Istituto di Scienze e Tecnologie Molecolari (ISTM), Consiglio

Nazionale delle Ricerche, via G. Fantoli 16/15, 20138 Milano, Italy.

' Istituto di Scienze e Tecnologie Molecolari (ISTM), Consiglio Nazionale delle Ricerche, via C. Golgi 19, 20133 Milano, Italy.

* Corresponding Authors

Dr. A. Ponti: alessandro.ponti@istm.cnr.it

Dr. G. Molteni: giorgio.molteni@unimi.it

\begin{abstract}
Colloidal nanoparticles of Earth-abundant, first-row transition metal oxides and sulfide, namely magnetite $\left(\mathrm{Fe}_{3} \mathrm{O}_{4}\right)$, manganese and cobalt ferrite, $\left(\mathrm{MnFe}_{2} \mathrm{O}_{4}, \mathrm{CoFe}_{2} \mathrm{O}_{4}\right)$, manganese(II) oxide (MnO) and sulfide $(\alpha-\mathrm{MnS})$, were used as catalysts in the cycloaddition between azides and methyl propiolate. The presence of these nanoparticles allowed us to carry out the cycloadditions at milder conditions and with a regioselectivity comparable to the classic "metal-free" thermal processes. Ferrite nanoparticles gave higher conversion than $\mathrm{MnO}$ and $\alpha-\mathrm{MnS}$ nanoparticles. The feasibility of the cycloaddition onto 1,2disubstituted acetylenes was also proved. Ferrite nanocatalysts could be magnetically recovered and reused without significant loss of catalytic activity. Density functional theory (DFT) calculations support a mechanistic hypothesis that attributes the increased cycloaddition rate to the adsorption of the azide onto to the nanocatalyst surface.
\end{abstract}

Keywords. Cycloaddition, azide, alkyne, 1,2,3-triazole, nanoparticle, ferrite. 


\section{Introduction}

Catalysis by inorganic nanoparticles (NPs) is a very rapidly growing field ${ }^{1}$ since catalytically active NPs may combine the advantages and overcome the shortcomings of the homogeneous and heterogeneous approaches to catalysis. ${ }^{2} \mathrm{NP}$ catalysts are robust, easily recoverable and recyclable, like heterogeneous catalysts. Colloidal NPs - as opposed to supported NPs - are well dispersed within the reaction medium, thus increasing the available catalytic surface and improving the diffusion of reactants and products, though they cannot achieve the unimpeded mass transfer and high accessibility of active sites typical of homogeneous catalysts.

The choice route to the 1,2,3-triazole ring is provided by the azide-alkyne cycloaddition. ${ }^{3}$ Although such a reaction dates to the end of the 19 th century, ${ }^{4}$ its mechanism and synthetic applications were disclosed by Huisgen in the early 1960s.5,6,7 Forty years later, the concept of "click" reaction allowed for the first time the fully regioselective cycloaddition to 4-substituted-1,2,3-triazoles. ${ }^{8,9}$ Quite recently, novel homogeneous metallorganic catalysts accomplished the regioselective synthesis of the 5substituted, complementary isomer. ${ }^{10,11,12,13,14}$ Due to its robustness, it is fair to say that the azide-alkyne cycloaddition has assumed a prominent position at the interface between chemistry, biology, and materials science. ${ }^{15,16}$ As examples, some derivatives of 1,2,3-triazoles are effective drugs against epilepsy ${ }^{17}$ and diabetes, ${ }^{18}$ and 1,2,3-triazolium-containing ionic liquids containing mixed polymeric materials are of great interest as immobilised catalysts. ${ }^{19}$

In 2006, some of us introduced the use of colloidal $\mathrm{Cu} @ \mathrm{Cu}_{2} \mathrm{O} \mid \mathrm{CuO}$ NPs as effective catalysts for the cycloaddition of organic azides and terminal alkynes to 1,2,3-triazoles. ${ }^{20}$ Several examples followed, 21,22,23 which involved colloidal $\mathrm{Cu},{ }^{24,}{ }^{25} \mathrm{Fe} @ \mathrm{Cu},{ }^{26} \mathrm{Cu}_{2} \mathrm{O},{ }^{27,}{ }^{28} \mathrm{CuO},{ }^{29}$ and $\mathrm{CuFe}_{2} \mathrm{O}_{4}{ }^{30,} 31 \mathrm{NPs}$, in some cases extending this approach to aqueous solvents. ${ }^{24,26,27,29,31}$ In these reactions, the 4-substituted triazole is formed and internal alkynes do not react, as in the homogeneous copper-catalysed 'click' reaction. The NP-catalysed mechanism was shown to be similar ${ }^{32}$ to that of the homogeneous reaction. ${ }^{33} \operatorname{Ag}_{2} \mathrm{O}$ NPs also catalyse this cycloaddition but the mechanism seems different as electron-poor azides gave a mixture of the 4- and 5-substituted isomers. ${ }^{34}$

We then turned our attention to cheaper metals as possible nanocatalysts for the azide-alkyne cycloaddition. We selected in particular iron as an abundant, inexpensive, environmentally friendly and biocompatible metal and focused on its oxide $\mathrm{Fe}_{3} \mathrm{O}_{4}$ (magnetite) for its robustness, stability and magnetization, which makes magnetite nanocatalysts easy to recover by an external magnet. ${ }^{35}$ Colloidal iron oxide NPs catalyse a number of organic reactions, mainly oxidations ${ }^{1,35}$ but also polymerization, ${ }^{36}$ isomerization, ${ }^{37,38}$ hydrogenation, ${ }^{39}$ alkylation and alkenylation, ${ }^{\mathbf{1}}$ and reactions involving the oxidative activation of the $\mathrm{C}-\mathrm{H}$ bond. ${ }^{35} \mathrm{We}$ have recently shown that magnetite NPs are good catalysts for the cycloaddition of nitrilimines to alkenes, alkynes, and activated nitriles. ${ }^{40}$ To widen the scope of our 
investigation about azide-alkyne cycloaddition, we also considered the iron neighbours manganese and cobalt, despite their slightly higher impact on health and environment. This, in addition to magnetite NPs, we considered NPs made of either mixed ferrite $\left(\mathrm{MnFe}_{2} \mathrm{O}_{4}, \mathrm{CoFe}_{2} \mathrm{O}_{4}\right)$ and manganese(II) oxide (MnO) and sulfide $(\alpha-\mathrm{MnS})$. The $\mathrm{Mn}$ and Co ferrite NPs have found use as catalysts for organic reactions. ${ }^{41,42}$ Here we show that colloidal magnetite NPs - along with Mn and Co ferrite, Mn(II) oxide and sulfide NPs - are effective catalysts for the cycloaddition between organic azides and both terminal and internal alkynes.

\section{Experimental section}

\section{Synthesis of iron oxide $\left(\mathrm{Fe}_{3} \mathrm{O}_{4}\right)$ nanoparticles}

$\mathrm{Fe}_{3} \mathrm{O}_{4}$ nanoparticles were synthesized by modification of a reported procedure. ${ }^{43}$ In a $50-\mathrm{ml}$ three-necked round-bottom flask, equipped with condenser, thermocouple, and rubber septum, oleic acid (OlAc, 2.4 $\mathrm{ml}, 7.5 \mathrm{mmol}$ ) was dissolved in $10 \mathrm{ml}$ of octadec-1-ene (ODE) under stirring and argon atmosphere. The solution was heated to $105{ }^{\circ} \mathrm{C}$ and degassed three times by vacuum-argon cycles. After $40 \mathrm{~min}$. $\mathrm{Fe}(\mathrm{CO})_{5}$ ( $330 \mu \mathrm{l}, 2.5 \mathrm{mmol}$ ) was injected through the rubber septum. The reaction mixture was heated to $320{ }^{\circ} \mathrm{C}$ (heating rate $15^{\circ} \mathrm{C} / \mathrm{min}$ ) and aged at that temperature for $3 \mathrm{~h}$. After cooling at $\mathrm{RT}$, the reaction crude was precipitated with acetone and the nanoparticles were collected by centrifugation ( $3400 \mathrm{~g}, 10 \mathrm{~min})$. The nanoparticles were repeatedly washed with acetone and collected by centrifugation $(3400 \mathrm{~g}, 10 \mathrm{~min})$. The resulting OlAc-coated NPs were dispersed in toluene at a concentration of $3.22 \mathrm{~g}_{\mathrm{Fe}} / 1$. The isolated yield was $58 \%$ with respect to $\mathrm{Fe}(\mathrm{CO})_{5}$.

\section{Synthesis of mixed ferrite $\left(\mathrm{MFe}_{2} \mathrm{O}_{4}, \mathrm{M}=\mathrm{Mn}, \mathrm{Co}\right)$ nanoparticles}

$\mathrm{MFe}_{2} \mathrm{O}_{4}$ nanoparticles were synthesized following of a reported procedure ${ }^{44}$ except for the use of 1,2hexadecanediol instead of 1,2-tetradecanediol. The molar ratio $\mathrm{M}(\mathrm{acac})_{2}$ :Fe(acac) $)_{3}$ was 1:2 (acac = acetylacetonate). In a 100-ml three-necked round-bottom flask, equipped with condenser, thermocouple, and rubber septum, oleic acid (OlAc, $1.0 \mathrm{ml}, 3.15 \mathrm{mmol})$, oleylamine $(1.0 \mathrm{ml}, 3.04 \mathrm{mmol}), \mathrm{Fe}(\mathrm{acac})_{3}$ $(0.350 \mathrm{~g}, 0.990 \mathrm{mmol})$, and $\mathrm{M}(\mathrm{acac})_{2}(0.495 \mathrm{mmol}, \mathrm{M}=\mathrm{Mn}, \mathrm{Co})$ were dissolved in $25 \mathrm{ml}$ of dibenzylether under stirring and argon atmosphere. The reaction mixture was rapidly heated to $120{ }^{\circ} \mathrm{C}$ and held at that temperature for $30 \mathrm{~min}$ under vacuum and $30 \mathrm{~min}$ under argon. Next, it was heated to 210 ${ }^{\circ} \mathrm{C}$ (heating rate: $8{ }^{\circ} \mathrm{C} / \mathrm{min}$ ) and held at that temperature for $2 \mathrm{~h}$ under argon. Finally, the reaction mixture 
was heated to $300{ }^{\circ} \mathrm{C}$ (heating rate: $3{ }^{\circ} \mathrm{C} / \mathrm{min}$ ) and aged at that temperature for $1 \mathrm{~h}$. After the high temperature synthesis, the nanoparticles were washed 5 times with acetone/ethanol mixture and collected by centrifugation (3400 $\mathrm{g}, 10 \mathrm{~min})$. The resulting nanoparticles were dispersed in toluene at a concentration $2.16 \mathrm{~g}_{\mathrm{Fe}} / 1\left(\mathrm{MnFe}_{2} \mathrm{O}_{4}\right)$ and $2.31 \mathrm{~g}_{\mathrm{Fe}} / 1\left(\mathrm{CoFe}_{2} \mathrm{O}_{4}\right)$. The isolated yield was about 30\% with respect to $\mathrm{Fe}(\mathrm{acac})_{3}$.

\section{Synthesis of manganese(II) oxide (MnO) and manganese(II) sulfide ( $\alpha$-MnS) nanoparticles}

$\mathrm{MnO}$ and $\alpha-\mathrm{MnS}$ nanoparticles were synthesized adapting reported procedures. ${ }^{45}$ The actual procedure for $\mathrm{MnO}$ and $\alpha-\mathrm{MnS}$ nanoparticles is as follows. In a $25-\mathrm{ml}$ two-necked round-bottom flask, equipped with condenser, thermocouple, $\mathrm{Mn}_{2}(\mathrm{CO})_{10}(104 \mathrm{mg}, 0.267 \mathrm{mmol})$, stearic acid (StAc, $\left.448 \mathrm{mg}, 1.57 \mathrm{mmol}\right)$, and elemental sulfur (34 mg, $1.1 \mathrm{mmol}$ ) was dissolved in $1.1 \mathrm{ml}$ of octadec-1-ene (ODE) under stirring and argon atmosphere. The solution was heated to $320{ }^{\circ} \mathrm{C}$ (heating rate $10{ }^{\circ} \mathrm{C} / \mathrm{min}$ ) and aged at that temperature for $1 \mathrm{~h}$. After cooling at RT, the solid reaction crude was dissolved in about $3 \mathrm{ml}$ of toluene and added with $12 \mathrm{ml}$ of ethanol. The nanoparticles were collected by centrifugation $(3400 \mathrm{~g}, 10 \mathrm{~min})$ after adding. Next, the nanoparticles were washed with ethanol (5\%) and acetone (x 2) collected and by centrifugation ( $3400 \mathrm{~g}, 10 \mathrm{~min}$ ). Extensive washing is required to eliminate the excess stearic acid. The resulting StAc-coated $\mathrm{MnO}$ nanoparticles were dispersed in $n$-hexane at a concentration of $1.21 \mathrm{~g}_{\mathrm{Mn}} / 1$. To obtain $\alpha-\mathrm{MnS}$ nanoparticles, the above procedure was followed dissolving $\mathrm{Mn}_{2}(\mathrm{CO})_{10}(107 \mathrm{mg}, 0.273$ mmol), stearic acid (StAc, $298 \mathrm{mg}, 1.05 \mathrm{mmol}$ ), and elemental sulfur (68 mg, $2.1 \mathrm{mmol}$ ) in $1.1 \mathrm{ml}$ of ODE. The resulting StAc-coated $\alpha-\mathrm{MnS}$ nanoparticles were dispersed in $n$-hexane at a concentration of $1.05 \mathrm{~g}_{\mathrm{Mn}} / 1$.

\section{Cycloaddition between azides 1 and methyl propiolate in the presence of CuI. General procedure} A solution of azide $1(0.5 \mathrm{mmol})$ and methyl propiolate $(84 \mathrm{mg}, 1.0 \mathrm{mmol})$ in dry toluene $(2.0 \mathrm{ml})$ was added with $\mathrm{CuI}(190 \mathrm{mg}, 1.0 \mathrm{mmol})$. The heterogeneous mixture was stirred at $20^{\circ} \mathrm{C}$ and the reaction was monitored with periodic TLC (hexane/ethyl acetate 7:3). After $9 \mathrm{~h}\left(\mathbf{4 a}, \mathrm{R}_{\mathrm{f}}=0.35\right), 18 \mathrm{~h}\left(\mathbf{4} \mathbf{b}, \mathrm{R}_{\mathrm{f}}=0.13\right)$ or $6 \mathrm{~h}\left(\mathbf{4 c}, \mathrm{R}_{\mathrm{f}}=0.28\right)$, the undissolved material was filtered over a celite pad and washed with acetone $(3 \times 2$ $\mathrm{ml})$. The collected solvents were evaporated under reduced pressure and the residue was crystallized with diisopropyl ether affording 4-substituted-1,2,3-triazoles 4a-c.

\section{Uncatalysed cycloaddition between azides 1 and methyl propiolate 2. General procedure}

A solution of azide $1(0.5 \mathrm{mmol})$ and methyl propiolate $(67 \mathrm{mg}, 0.8 \mathrm{mmol})$ in dry toluene $(2.0 \mathrm{ml})$ was stirred at the temperatures and the times listed in the Tables 3 and 4 . The reactions were monitored by 
TLC (hexane/ethyl acetate $7: 3$ ). The solvent was removed under reduced pressure and the residue was chromatographed on a silica gel column with hexane/ethyl acetate $7: 3$.

In the case of the reaction carried out at $20^{\circ} \mathrm{C}$ (Table 3 , entry 1), unchanged 1a was eluted first ( $83 \mathrm{mg}$, 55\%). Further elution gave 5-substituted-1,2,3-triazole 5a $\left(\mathrm{R}_{\mathrm{f}}=0.46\right)$ and 4-substituted-1,2,3-triazole 4a (44 mg, 23\%).

In the case of the reaction carried out at $75^{\circ} \mathrm{C}$ (Table 4 , entry 1$), \mathbf{5 b}\left(\mathrm{R}_{\mathrm{f}}=0.37\right)$ was eluted first, followed by $4 \mathbf{b}(67 \mathrm{mg}, 64 \%)$.

In the case of the reaction carried out at $90^{\circ} \mathrm{C}($ Table 4 , entry 7$), \mathbf{5 c}\left(R_{\mathrm{f}}=0.56\right)$ was eluted first, followed by $4 \mathrm{c}(75 \mathrm{mg}, 74 \%)$.

\section{Cycloaddition between azides 1 and methyl propiolate 2 in the presence of $\mathrm{Fe}_{3} \mathrm{O}_{4}$ nanoparticles}

A solution of azide $1(0.5 \mathrm{mmol})$, methyl propiolate $(67 \mathrm{mg}, 0.8 \mathrm{mmol})$ and $\mathrm{Fe}_{3} \mathrm{O}_{4}$ nanoparticles $(1 \mathrm{ml}, 58$ $\mu \mathrm{mol}$ of $\mathrm{Fe})$ in toluene $(1.0 \mathrm{ml})$ was stirred at the temperatures and the times listed in the Tables 3 and 4. The reaction crude was filtered over a celite pad and washed with ethyl acetate $(3 \times 3 \mathrm{ml})$. The collected solvents were evaporated under reduced pressure.

In the case of the reaction carried out at $20^{\circ} \mathrm{C}$ (Table 3, entry 4), the residue was chromatographed on a silica gel column with hexane/ethyl acetate $7: 3$. Unchanged 1a was eluted first (60 mg, 40\%). Further elution gave a mixture of 1,2,3-triazoles $4 \mathbf{a}$ and $\mathbf{5 a}(110 \mathrm{mg}, 57 \%)$ in the ratio $65: 35$ as determined by ${ }^{1} \mathrm{H}$ NMR.

In the case of the reactions carried out at $45^{\circ} \mathrm{C}$ (Table 3 , entry 5 and Table 4 , entries 2 and 8 ), $75^{\circ} \mathrm{C}$ (Table 3, entry 6) and $95^{\circ} \mathrm{C}$ (Table 3, entry 7 ) the ratio $4: 5$ was determined by ${ }^{1} \mathrm{H}$ NMR.

\section{Cycloaddition between azides 1 and methyl propiolate 2 in the presence of $\mathrm{CoFe}_{2} \mathrm{O}_{4}$ nanoparticles} A solution of azide $1(0.5 \mathrm{mmol})$, methyl propiolate $(67 \mathrm{mg}, 0.8 \mathrm{mmol})$ and $\mathrm{CoFe}_{2} \mathrm{O}_{4}$ nanoparticles $(0.66$ $\mathrm{ml}, 27 \mu \mathrm{mol}$ of $\mathrm{Fe}, 10 \mu \mathrm{mol}$ of $\mathrm{Co})$ in toluene $(1.34 \mathrm{ml})$ was stirred at $45^{\circ} \mathrm{C}$ for the times listed in Tables 3 , entry 8 and Table 4, entries 3 and 9 . The reaction crude was filtered over a celite pad and washed with ethyl acetate $(3 \times 3 \mathrm{ml})$. The collected solvents were evaporated under reduced pressure.

The ratio $4: 5$ was determined by ${ }^{1} \mathrm{H}$ NMR of the residue.

\section{Cycloaddition between azides 1 and methyl propiolate 2 in the presence of $\mathrm{MnFe}_{2} \mathrm{O}_{4}$ nanoparticles} A solution of azide $1(0.5 \mathrm{mmol})$, methyl propiolate $(67 \mathrm{mg}, 0.8 \mathrm{mmol})$ and $\mathrm{MnFe}_{2} \mathrm{O}_{4}$ nanoparticles $(0.45$ $\mathrm{ml}, 17 \mu \mathrm{mol}$ of $\mathrm{Fe}, 6 \mu \mathrm{mol}$ of $\mathrm{Mn})$ in toluene $(1.55 \mathrm{ml})$ was stirred at $45^{\circ} \mathrm{C}$ for the times listed in Tables 3 , entry 9 and Table 4, entries 4 and 10. The reaction crude was filtered over a celite pad and washed with ethyl acetate $(3 \times 3 \mathrm{ml})$. The collected solvents were evaporated under reduced pressure. 
The ratio $4: 5$ was determined by ${ }^{1} \mathrm{H}$ NMR of the residue.

\section{Cycloaddition between azides 1 and methyl propiolate 2 in the presence of $\mathrm{MnO}$ nanoparticles}

A solution of azide $1(0.5 \mathrm{mmol})$, methyl propiolate $(67 \mathrm{mg}, 0.8 \mathrm{mmol})$ and $\mathrm{MnO}$ nanoparticles $(0.45 \mathrm{ml}$, $10 \mu \mathrm{mol}$ of $\mathrm{Mn})$ in toluene $(1.55 \mathrm{ml})$ was stirred at $45^{\circ} \mathrm{C}$ for the times listed in Tables 3 , entry 10 and Table 4, entries 5 and 11 . The reaction crude was filtered over a celite pad and washed with ethyl acetate ( $3 \times 3 \mathrm{ml})$. The collected solvents were evaporated under reduced pressure.

The ratio $4: 5$ was determined by ${ }^{1} \mathrm{H}$ NMR of the residue.

\section{Cycloaddition between azides 1 and methyl propiolate 2 in the presence of MnS nanoparticles}

A solution of azide $1(0.5 \mathrm{mmol})$, methyl propiolate $(67 \mathrm{mg}, 0.8 \mathrm{mmol})$ and $\mathrm{MnS}$ nanoparticles $(0.45 \mathrm{ml}$, $8 \mu \mathrm{mol}$ of $\mathrm{Mn})$ in toluene $(1.55 \mathrm{ml})$ was stirred at $45^{\circ} \mathrm{C}$ for the times listed in Tables 4 , entry 11 and Table 4 , entries 6 and 12. The reaction crude was filtered over a celite pad and washed with ethyl acetate $(3 \times 3$ $\mathrm{ml})$. The collected solvents were evaporated under reduced pressure.

The ratio $4: 5$ was determined by ${ }^{1} \mathrm{H}$ NMR of the residue.

\section{Uncatalysed cycloaddition between azide 1a and DMAD 3}

A solution of azide 1a $(0.15 \mathrm{~g}, 0.5 \mathrm{mmol})$ and DMAD $3(0.14 \mathrm{~g}, 1.0 \mathrm{mmol})$ in toluene $(2.0 \mathrm{ml})$ was stirred at the temperatures and the times listed in the Table 5. The reactions were monitored by TLC (hexane/ethyl acetate $7: 3$ ). Evaporation of the solvent gave a residue which was crystallized with diisopropyl ether affording pure $6\left(\mathrm{R}_{\mathrm{f}}=0.6\right)$, reaction at $20^{\circ} \mathrm{C}: 0.16 \mathrm{~g}, 72 \%$; reaction at $95^{\circ} \mathrm{C}: 0.22 \mathrm{mg}$, $99 \%$.

\section{Cycloaddition between azide $1 \mathrm{a}$ and DMAD 3 in the presence of $\mathrm{Fe}_{3} \mathrm{O}_{4}$ nanoparticles}

A solution of azide $1 \mathrm{a}(0.15 \mathrm{~g}, 0.5 \mathrm{mmol})$, DMAD $(0.14 \mathrm{~g}, 1.0 \mathrm{mmol})$ and $\mathrm{Fe}_{3} \mathrm{O}_{4}$ nanoparticles $(0.25 \mathrm{ml}$, $14 \mu \mathrm{mol}$ of $\mathrm{Fe})$ in toluene $(1.75 \mathrm{ml})$ was stirred at the temperatures and the times listed in the Table 5. Evaporation of the solvent gave a residue which was crystallized with diisopropyl ether affording pure 6 (reaction at $20^{\circ} \mathrm{C}: 0.22 \mathrm{~g}, 99 \%$, reaction at $95^{\circ} \mathrm{C}: 0.22 \mathrm{mg}, 99 \%$ ).

\section{Cycloaddition between azide 1a and DMAD 3 in the presence of $\mathrm{MnFe}_{2} \mathrm{O}_{4}$ nanoparticles}

A solution of azide 1a $(0.15 \mathrm{~g}, 0.5 \mathrm{mmol})$, DMAD $(0.14 \mathrm{~g}, 1.0 \mathrm{mmol})$ and $\mathrm{MnFe}_{2} \mathrm{O}_{4}$ nanoparticles $(0.44$ $\mathrm{ml}, 17 \mu \mathrm{mol}$ of $\mathrm{Fe}, 6 \mu \mathrm{mol}$ of $\mathrm{Mn})$ in toluene $(1.56 \mathrm{ml})$ was stirred at $20^{\circ} \mathrm{C}$ for $20 \mathrm{~h}$. Evaporation of the solvent gave a residue which was crystallized with diisopropyl ether affording pure 6 (0.20 g, 91\%). 


\section{Recycling of the $\mathrm{Fe}_{3} \mathrm{O}_{4} \mathrm{NP}$ catalyst in the cycloaddition between azide 1c and methyl propiolate 2 .}

The recycling experiments were carried out using dichloromethane as a solvent because it is easier to keep the reaction temperature constant and to isolate products and NPs.

First run. In a $100 \mathrm{~mL}$ cylindrical reaction funnel, phenylazide $1 \mathrm{c}(0.50 \mathrm{~g}, 4.2 \mathrm{mmol})$ and methyl propiolate 2 (0.38 g, $4.5 \mathrm{mmol})$ were dissolved in dry dichloromethane $(16.3 \mathrm{~mL})$. $\mathrm{Fe}_{3} \mathrm{O}_{4} \mathrm{NPs}(47 \mathrm{mg}$, $0.84 \mathrm{mmol}$ of $\mathrm{Fe}$ ) dispersed in chloroform $(4.7 \mathrm{~mL})$ were added dropwise in $2 \mathrm{~min}$. The mixture was submitted to vigorous magnetic stirring for $6 \mathrm{~h}$ at $40^{\circ} \mathrm{C}$. The undissolved material was recovered with an external magnet, washed with dichloromethane $(8 \mathrm{~mL})$ and recovered again with an external magnet. The mother solution was washed with water $(3 \times 25 \mathrm{~mL})$, dried over sodium sulfate and evaporated under reduced pressure. The crude was crystallised with diisopropyl ether giving a mixture of the isomeric triazoles $\mathbf{4 a}+\mathbf{5 a}(0.76 \mathrm{~g}, 89 \%)$.

Subsequent runs $\left(2^{\text {nd }}-5^{\text {th }}\right)$. The recovered NPs were dispersed in dry dichloromethane $(21 \mathrm{~mL})$ and amounts of $1 \mathrm{c}$ and 2 were added as in the first run. After $6 \mathrm{~h}$ at $40^{\circ} \mathrm{C}$, the isomeric triazoles were isolated and the NPs recovered and washed as in the first run.

The recycling experiments where the NP mass after each run was measured were carried out as above except that the recovered NPs were dried with a rotary pump $(0.05 \mathrm{mmHg})$ for $1 \mathrm{~h}$ and weighted before dispersion in dichloromethane for the next cycle.

\section{Characterization.}

Transmission electron microscopy (TEM) images and electron diffraction (ED) patterns were collected using a Zeiss LIBRA 200FE microscope. The TEM specimen was prepared by evaporating in air a drop of diluted NP dispersion on a carbon coated copper grid. The size distribution of the iron oxide cores was obtained analysing TEM images by the software PEBBLES. ${ }^{51}$ PEBBLES is freely available from the authors (http://pebbles.istm.cnr.it). FT-IR spectra were collected using a Thermo Nicolet NEXUS 670 FTIR spectrometer. The specimen for FTIR was prepared by grinding and pelleting dry NPs with $\mathrm{KBr}$ (NP:KBr 1:100 w/w). ${ }^{1} \mathrm{H}$ NMR (300 MHz) and ${ }^{13} \mathrm{C}$ NMR (75 MHz) spectra were taken with a Bruker Fourier 300 spectrometer (in $\mathrm{CDCl}_{3}$ solutions at room temperature). Chemical shifts are given as parts per million from tetramethylsilane. Coupling constants $(J)$ values are given in hertz and are quoted to $\pm 0.1 \mathrm{~Hz}$ consistently with NMR machine accuracy. Element analyses were carried out by a Perkin-Elmer 2400 series II CHNS/O Analyzer.

\section{Computational methods.}

Periodic Density Functional (DFT) computations were carried out by the SIESTA 4.0 suite of programs. 46 The surface of a magnetite nanoparticle was simulated as a two-dimensional supercell reproducing the 
stoichiometry of the bulk compound. In the case of the (100) slab the cell contains 62 atoms plus one 1c molecule. In both systems the 1c moiety is adsorbed onto an under-coordinated surface Fe atom. The surface unit cells was designed such that the overall stoichiometry reproduced the oxygen to iron ratio of the bulk material. When necessary, surface atoms were saturated with $-\mathrm{H}$ and $-\mathrm{OH}$ groups to reproduce their formal oxidation state. DFT computations were conducted with the PBE exchange and correlation functionals. In accordance with literature results, ${ }^{47}$ we included also a $U$ term for Fe atoms, amounting to $4 \mathrm{eV}$, to reproduce at best the DOS of bulk $\mathrm{Fe}_{3} \mathrm{O}_{4}$. All atoms except hydrogen were assigned a splitvalence basis set of double zeta quality for valence electrons, while norm-conserving Troullier-Martins pseudopotentials were adopted to describe the core electrons. The reciprocal space was sampled with a $8 \times 8 k$-points grid. Convergence of the wavefunction was facilitated by imposing an electronic temperature of $300 \mathrm{~K}$ within a Fermi-Dirac occupation statistics. All geometries were fully optimized. Figure 7 compares energies belonging to different computations, i.e. having different vacuum energy levels, and hence the DOS of $\mathbf{1 c}$ and energy levels of $\mathbf{2}$ were aligned so that the distance between the lowest eigenvalues shown in the figure reproduces the value obtained in a gas phase computation including both molecules in a non-interacting configuration.

Molecular DFT calculations related to the cycloaddition of $\mathbf{2}$ and $\mathbf{1 c}, \mathbf{1 c}-\mathrm{Fe}(\mathrm{OH})_{3}$ and $\mathbf{1 c}-\mathrm{Fe}_{2}(\mathrm{OH})_{4}$ were carried using the OPBE functional, which was shown to perform well with Fe(III) complexes, ${ }^{48}$ the LANL2 pseudopotential, and the LANL2DZ basis set as implemented in the Gaussian09 Suite. ${ }^{49}$ All geometries were fully optimized and harmonic analysis showed that they were true energy minima (no imaginary frequency) or transition states (one imaginary frequency), as required.

\section{Results and discussion}

\subsection{Nanoparticles synthesis and characterization}

Transition metal oxides $\left(\mathrm{Fe}_{3} \mathrm{O}_{4}, \mathrm{MnFe}_{2} \mathrm{O}_{4}, \mathrm{CoFe}_{2} \mathrm{O}_{4}, \mathrm{MnO}\right)$ and $\alpha-\mathrm{MnS}$ NPs were synthesized by the solvothermal decomposition of the appropriate precursors as detailed in the Experimental section. All NPs used in this study consist of a nanocrystal coated with a layer of fatty acid and are colloidally stable in apolar solvents. The main features of the NPs are collected in Table 1. The concentration of Fe (ferrites) and that of $\mathrm{Mn}(\mathrm{MnO}$ and $\mathrm{MnS})$ in the NP dispersions were obtained by spectrophotometry 50 and chemical analysis (see ESI), respectively. 
Table 1. Main features of as-synthesized metal oxide and sulfide nanoparticles.

\begin{tabular}{|c|c|c|c|c|c|c|c|}
\hline NP & $\begin{array}{l}C_{\mathrm{Fe}} \\
(\mathrm{g} / \mathrm{l})\end{array}$ & $\begin{array}{l}C_{\mathrm{M}} \\
(\mathrm{g} / \mathrm{l})\end{array}$ & $\begin{array}{l}\text { Dispersion } \\
\text { solvent }\end{array}$ & Coating & $<d>\mathbf{a}$ & $\sigma_{d} \mathbf{b}$ & $\begin{array}{l}\sigma_{d} /<d> \\
(\%)\end{array}$ \\
\hline $\mathrm{Fe}_{3} \mathrm{O}_{4}$ & 3.22 & - & toluene & oleic acid & 11.9 & 0.6 & 5 \\
\hline $\mathrm{CoFe}_{2} \mathrm{O}_{4} \mathbf{c}$ & 2.31 & $0.85(\mathrm{Co})$ & toluene & oleic acid & 10 & 2.0 & 20 \\
\hline $\mathrm{MnFe}_{2} \mathrm{O}_{4}$ & 2.16 & $0.73(\mathrm{Mn})$ & toluene & oleic acid & 8.6 & 1.2 & 14 \\
\hline $\mathrm{MnO}$ & - & $1.21(\mathrm{Mn})$ & $n$-hexane & stearic acid & 11.6 & 1.6 & 14 \\
\hline$\alpha-\mathrm{MnS}$ & - & $1.05(\mathrm{Mn})$ & $n$-hexane & stearic acid & 44 & 12 & 27 \\
\hline
\end{tabular}

${ }^{\mathbf{a}}$ Median equivalent diameter (nm). ${ }^{\mathbf{b}}$ Diameter standard deviation (nm). ${ }^{\mathbf{c}} \mathrm{CoFe}_{2} \mathrm{O}_{4} \mathrm{NPs}$ have elongated shape with major axis $=(12 \pm 3) \mathrm{nm}(24 \%)$, minor axis $=(9 \pm 2) \mathrm{nm}(20 \%)$, aspect ratio $=(1.3 \pm 0.2)(15 \%)$.

Transmission electron microscopy (TEM) images of as-synthesized NPs can be found in Figure 1(a-e) (wide field TEM images can be found in the ESI, Figure S1). The size distribution of the NPs (see ESI, Figure S2) was obtained by analysing TEM images by the software PEBBLES. ${ }^{51}$ Magnetite NPs are spherical and have a very small size dispersion. Manganese (spherical) and cobalt (irregular) ferrite NPs are slightly smaller and have larger size dispersion. Both are slightly deficient in the divalent metal, as evidenced by electron energy loss spectroscopy (EELS). Their composition can be expressed as $\mathrm{Co}_{0.78} \mathrm{Fe}_{2.22} \mathrm{O}_{4}$ and $\mathrm{Mn}_{0.77} \mathrm{Fe}_{2.23} \mathrm{O}_{4}$. Octahedral MnO NPs are similar in size to $\mathrm{Fe}_{3} \mathrm{O}_{4} \mathrm{NPs}$ but have larger size dispersion. $\alpha-\mathrm{MnS}$ NPs are much larger and have spheroidal shape. Electron diffraction (Figure 2) allowed us to identify the nanocrystals as cubic ferrites (spinel structure) $\mathrm{Fe}_{3} \mathrm{O}_{4}, \mathrm{CoFe}_{2} \mathrm{O}_{4}, \mathrm{MnFe}_{2} \mathrm{O}_{4}$ and as rock-salt structure $\mathrm{MnO}$ and $\alpha-\mathrm{MnS}$. It should however be noted that the poor resolution of the diffraction pattern prevented us to distinguish between magnetite $\left(\mathrm{Fe}_{3} \mathrm{O}_{4}\right)$ and maghemite $\left(\gamma-\mathrm{Fe}_{2} \mathrm{O}_{3}\right)$, so that partial oxidation of magnetite NPs cannot be excluded. 

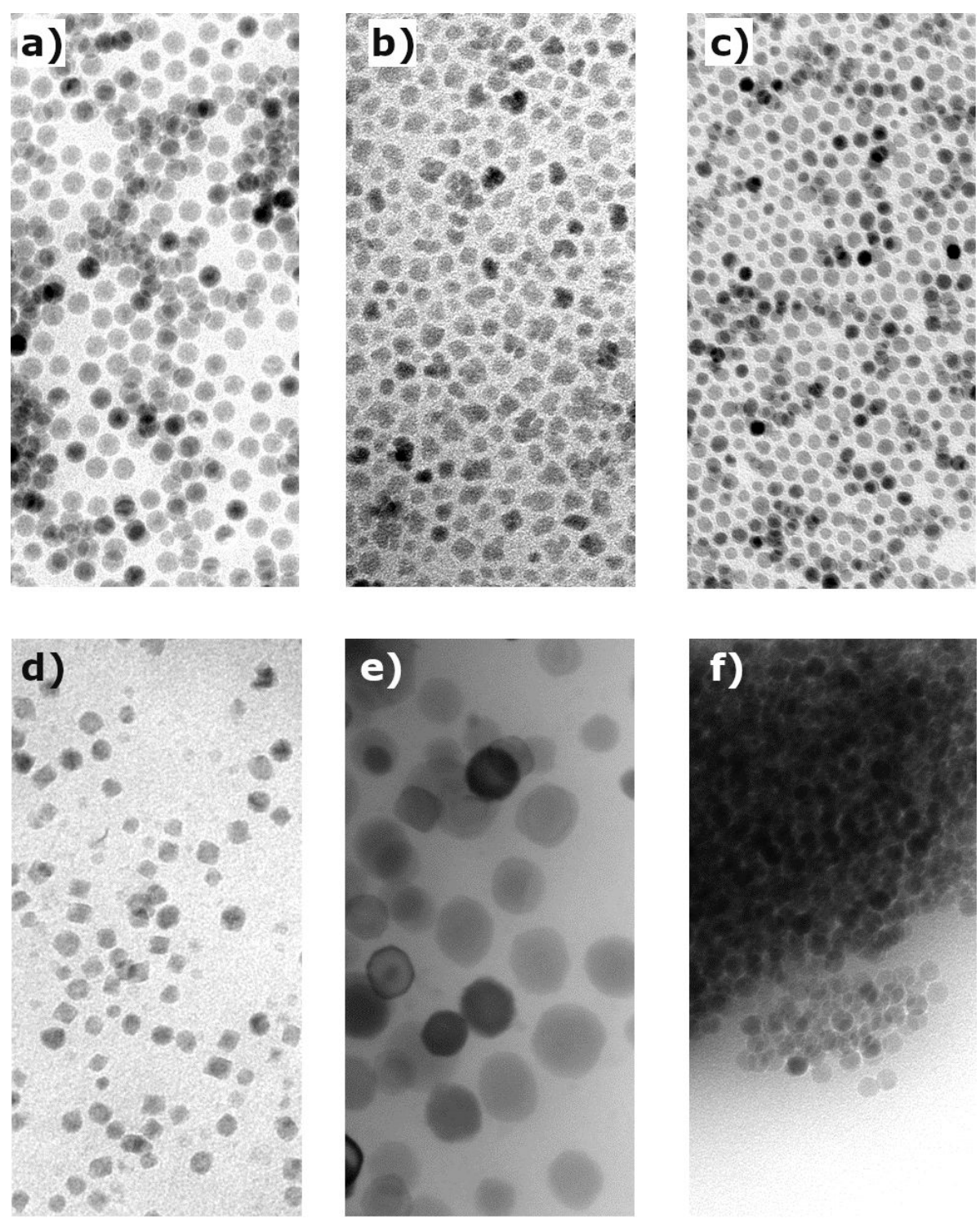

Figure 1. TEM images of as-synthesized (a-e) and used (f) nanoparticles. a) $\mathrm{Fe}_{3} \mathrm{O}_{4}$; b) $\mathrm{CoFe}_{2} \mathrm{O}_{4}$; c) $\mathrm{MnFe}_{2} \mathrm{O}_{4}$; d) $\mathrm{MnO}$; e) $\alpha-\mathrm{MnS}$; f) $\mathrm{Fe}_{3} \mathrm{O}_{4}$ after 5 runs. 

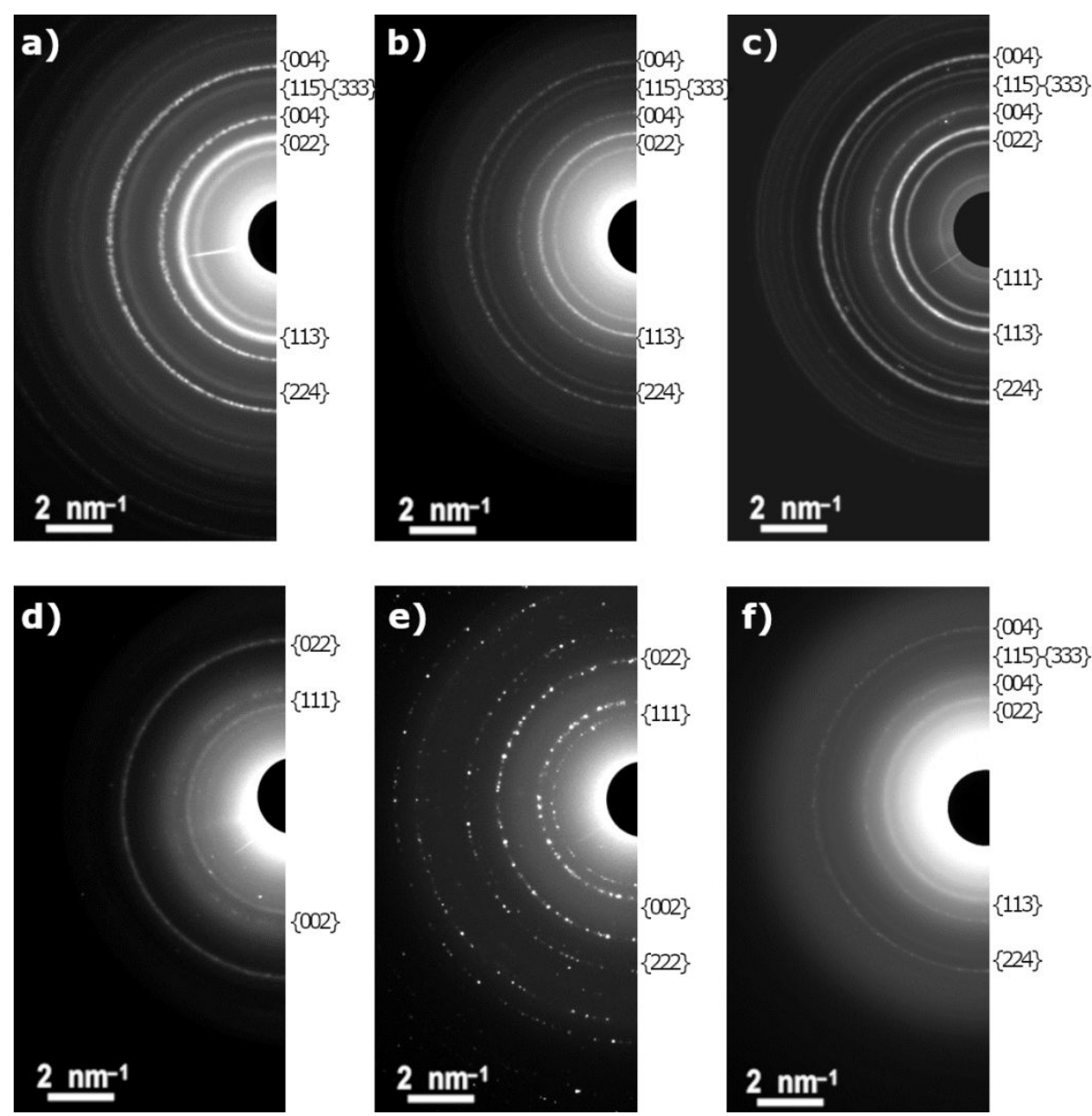

Figure 2. Electron diffraction patterns of as-synthesized (a-e) and used (f) nanoparticles. a) $\mathrm{Fe}_{3} \mathrm{O}_{4}$; b) $\mathrm{CoFe}_{2} \mathrm{O}_{4}$; c) $\mathrm{MnFe}_{2} \mathrm{O}_{4}$; d) $\mathrm{MnO}$; e) $\alpha-\mathrm{MnS}$; f) $\mathrm{Fe}_{3} \mathrm{O}_{4}$ after 5 runs. Patterns in a), b), c) and f) are consistent with the spinel structure; patterns in d) and e) are consistent with the rock-salt structure

The FT-IR spectra of the NPs confirmed that they are coated with a layer of fatty acid in the carboxylate form. The spectra of $\mathrm{Fe}_{3} \mathrm{O}_{4}$ and $\alpha-\mathrm{MnS}$ NPs are shown in Figure 3 as examples of NPs coated with oleic and stearic acid, respectively. Both spectra display the characteristic peaks of fatty acid anions: the $\mathrm{C}-\mathrm{H}$ stretching vibration of $\mathrm{CH}_{2}$ and $\mathrm{CH}_{3}$ groups $\left(2956-2851 \mathrm{~cm}^{-1}\right)$ and the symmetric and asymmetric stretches of the $\mathrm{COO}^{-}$group (ca. 1550 and $\left.1430 \mathrm{~cm}^{-1}\right)$. The weak peak at $3004 \mathrm{~cm}^{-1}\left(\mathrm{C}-\mathrm{H}\right.$ stretching of sp${ }^{2}$ carbon) and the strong peak at $590 \mathrm{~cm}^{-1}$ (Fe-O stretching) are only present in the spectrum of oleic acid coated $\mathrm{Fe}_{3} \mathrm{O}_{4}$ NPs. The density of the fatty acid ligands on the NP surface affects both the number of catalytic sites and the ease by which the reactants and products can diffuse to and from the NP. The ligand density collected in Table 2 were calculated by dividing the amount of fatty acid measured by elemental analysis by the surface area of the inorganic core calculated from TEM data. (The relevant equation is developed in the ESI) The ligand density is approximately constant among the NPs (1.44 1.52 molecules $\left./ \mathrm{nm}^{2}\right)$, except for the higher value of $\mathrm{MnFe}_{2} \mathrm{O}_{4} \mathrm{NPs}\left(1.93\right.$ molecules $\left./ \mathrm{nm}^{2}\right)$. These values 
are at the low side of the ligand density range $\left(1.2-6.6\right.$ molecules $\left./ \mathrm{nm}^{2}\right)$ for long-chain ligands, calculated from the data collected in Ref.. ${ }^{52}$

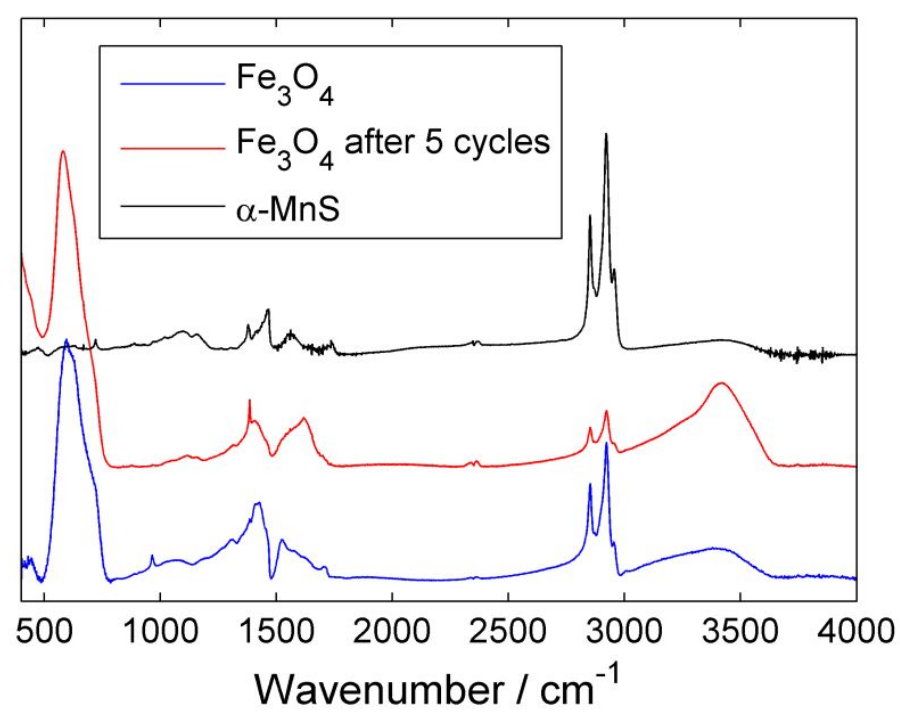

Figure 3. Selected FT-IR spectra of NP catalysts. Blue: fresh $\mathrm{Fe}_{3} \mathrm{O}_{4} \mathrm{NP}$ catalyst. Red: $\mathrm{Fe}_{3} \mathrm{O}_{4} \mathrm{NP}$ catalyst after 5 runs of the $\mathbf{1 c}+\mathbf{2}$ cycloaddition. Black: $\alpha-\mathrm{MnS}$ catalyst.

Table 2. Ligand density of the metal oxide and sulfide nanoparticles.

\begin{tabular}{llrrc}
\hline $\mathrm{NP}$ & Surface ligand & $\mathrm{C}(\mathrm{w} / \mathrm{w} \%)$ & $\mathrm{H}(\mathrm{w} / \mathrm{w} \%)$ & $\begin{array}{l}\text { Ligand density } \\
\left(\text { molecules } / \mathrm{nm}^{2}\right)\end{array}$ \\
\hline $\mathrm{Fe}_{3} \mathrm{O}_{4}$ & Oleic acid & 3.75 & 0.59 & 1.44 \\
$\mathrm{CoFe}_{2} \mathrm{O}_{4}$ & Oleic acid & 10.77 & 9.48 & 1.52 \\
$\mathrm{MnFe}_{2} \mathrm{O}_{4}$ & Oleic acid & 14.41 & 13.28 & 1.93 \\
$\mathrm{MnO}$ & Stearic acid & 6.12 & 6.68 & 1.45 \\
$\alpha-\mathrm{MnS}$ & Stearic acid & 1.84 & 2.03 & 1.51 \\
\hline
\end{tabular}

\subsection{Azide-alkyne cycloadditions}

Because of the well-known relevance of the azide-alkyne cycloadditions, ${ }^{53,54}$ we decided to investigate the reaction between azides $\mathbf{1}$ and methyl propiolate $\mathbf{2}$ or dimethylacetylene dicarboxylate 3 (Figure 4) in the presence of catalytic amounts of the NPs listed in Table 1. The appropriate reaction conditions were established by studying the reaction between the azide 1a and methyl propiolate $\mathbf{2}$ in anhydrous toluene (Scheme 1, Table 3), this azide was chosen since further synthetic transformations of cycloaddition products can be envisaged. ${ }^{55}$ 
<smiles>N#CCC(=O)Nc1ccccc1I</smiles>

$1 a$<smiles>[N]C[Pb]</smiles>

$1 b$<smiles>COC(=O)C#CC(=O)OC</smiles>

COOMe<smiles>C#CC</smiles>

2
3

Figure 4. Organic reactants for the NP-catalysed azide-alkyne cycloaddition.

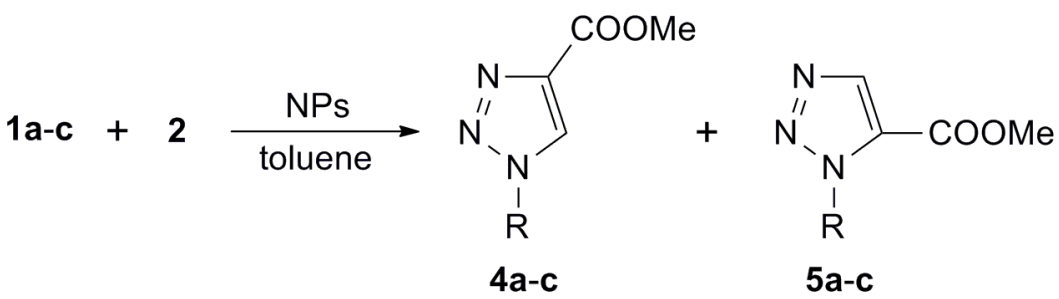

$$
\begin{aligned}
& a: R=\underbrace{\prime}_{H}=C_{O}
\end{aligned}
$$

Scheme 1. NP-catalysed cycloaddition between azides 1a-c and methyl propiolate 2. 
Table 3. Cycloaddition between azide 1a and methyl propiolate 2. ${ }^{\mathbf{a}}$

\begin{tabular}{llccllll}
\hline Entry & $\mathrm{NPs}$ & $\begin{array}{c}w_{\mathrm{Fe}} / w_{\mathbf{1 a}} \mathbf{b} \\
(\% \mathbf{0})\end{array}$ & $\begin{array}{c}w_{\mathrm{M}} / w_{\mathbf{1 a}} \mathbf{b} \\
(\% \mathbf{0})\end{array}$ & $\begin{array}{l}\text { Time } \\
(\mathrm{h})\end{array}$ & $\begin{array}{l}\mathrm{T} \\
\left({ }^{\circ} \mathrm{C}\right)\end{array}$ & $\begin{array}{l}\mathbf{4 a}+\mathbf{5 a} \\
(\%)\end{array}$ & $\mathbf{4 a}: \mathbf{5 a}$ \\
\hline 1 & - & - & - & 240 & 20 & $45^{\mathbf{c}}$ & $51: 49$ \\
2 & - & - & - & 24 & 45 & $57^{\mathbf{d}}$ & $57: 43$ \\
3 & - & - & - & 8 & 95 & 89 & $68: 32$ \\
4 & $\mathrm{Fe}_{3} \mathrm{O}_{4}$ & 21 & - & 24 & 20 & $57^{\mathbf{d}}$ & $65: 35^{\mathbf{e}}$ \\
5 & $\mathrm{Fe}_{3} \mathrm{O}_{4}$ & 21 & - & 7 & 45 & 95 & $83: 17^{\mathbf{e}}$ \\
6 & $\mathrm{Fe}_{3} \mathrm{O}_{4}$ & 21 & - & 3 & 75 & 88 & $67: 33^{\mathbf{e}}$ \\
7 & $\mathrm{Fe}_{3} \mathrm{O}_{4}$ & 21 & - & 2 & 95 & 80 & $68: 32^{\mathbf{e}}$ \\
8 & $\mathrm{CoFe}_{2} \mathrm{O}_{4}$ & 10 & $3.7(\mathrm{Co})$ & 8 & 45 & 93 & $75: 25^{\mathbf{e}}$ \\
9 & $\mathrm{MnFe}_{2} \mathrm{O}_{4}$ & 6.4 & $2.2(\mathrm{Mn})$ & 6 & 45 & 88 & $71: 29^{\mathbf{e}}$ \\
10 & $\mathrm{MnO}$ & - & $3.6(\mathrm{Mn})$ & 7 & 45 & 66 & $65: 35^{\mathbf{e}}$ \\
11 & $\mathrm{MnO}$ & - & $3.6(\mathrm{Mn})$ & 40 & 45 & 83 & $65: 35^{\mathbf{e}}$ \\
12 & $\alpha-\mathrm{MnS}$ & - & $3.1(\mathrm{Mn})$ & 8 & 45 & 62 & $70: 30^{\mathbf{e}}$ \\
13 & $\alpha-\mathrm{MnS}$ & - & $3.1(\mathrm{Mn})$ & 40 & 45 & 78 & $69: 31^{\mathbf{e}}$ \\
\hline
\end{tabular}

${ }^{\mathrm{a}}$ In the presence of iron(III) oleate or bulk $\mathrm{Fe}_{2} \mathrm{O}_{3}:(\mathbf{4 a}+\mathbf{5 a})<10 \%, \mathbf{4 a}: \mathbf{5 a}$ undetermined.

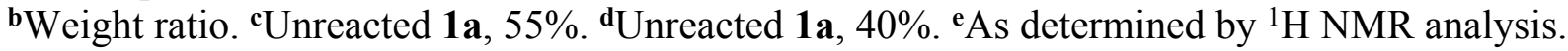

As can be seen from Table 3, the "metal free" reaction required long reaction times and yielded poor reactant conversion at room temperature (entry 1). By limiting the reaction time to $24 \mathrm{~h}$ at $45^{\circ} \mathrm{C}$, the conversion of the reactants was also low (entry 2). At higher temperature (entry 3 ) the reaction proceeded smoothly as expected for a typical thermal cycloaddition. Similar cycloadditions display similarly high yield when carried out in water. ${ }^{56}$ Both reactant conversion and reaction times were satisfactory in the presence of $\mathrm{Fe}_{3} \mathrm{O}_{4} \mathrm{NPs}$ at $45^{\circ} \mathrm{C}$ (entry 5), while at room temperature some amount of unreacted 1a was recovered (entry 4). At higher temperatures, good results were obtained (entries 6 and 7) although in these cases any catalytic activity of the $\mathrm{Fe}_{3} \mathrm{O}_{4} \mathrm{NPs}$ can be hardly revealed. Not unexpectedly, the heterogeneous reaction mixture in the presence of bulk $\mathrm{Fe}_{2} \mathrm{O}_{3}$ did not produce appreciable results. On the other hand, a homogeneous solution of iron(III) oleate were also ineffective, probably due to the crowded, hexacoordinated nature of the iron atom in this complex. In the presence of cobalt and manganese ferrite NPs (entries 8 and 9) at $45{ }^{\circ} \mathrm{C}$, results similar to that observed with $\mathrm{Fe}_{3} \mathrm{O}_{4}$ NPs were achieved. As far as manganese oxide and sulfide nanoparticles are concerned (entries 10 - 13), their ability to act as catalysts was poorer in comparison to the ferrite NPs. The ligand density is low enough to allow the reactants and products to diffuse to and from the metal oxide surface resulting in a generally good catalytic activity. The better performance of ferrite NPs, in particular $\mathrm{Fe}_{3} \mathrm{O}_{4}$, must be ascribed to the nature of the surface catalytic in view of the similar ligand density among the NPs. In all cases listed in Table 3 the observed 
regioselectivity, favouring the 4-cycloadduct in all cases, was higher than of the uncatalysed reaction although the results are not impressive since the regioselectivity is partial and not much different from that of the uncatalysed reaction (vide infra).

A related methodology has been published, ${ }^{57}$ in which naked maghemite $\left(\gamma-\mathrm{Fe}_{2} \mathrm{O}_{3}\right)$ NPs supported on hydroxyapatite were shown to catalyse the reaction of an organic halide with an alkyne in the presence of $\mathrm{NaN}_{3}$ in water at $100{ }^{\circ} \mathrm{C}$. This methodology is different from our one as to the nature of the NPs (naked, supported vs. coated, colloidal), the different reactants and solvent, and the reaction temperature. Furthermore, we extended the scope of the reaction and compared the activity of four different oxides and a sulfide.

In order to further investigate the behaviour of the metal oxide and sulfide NPs listed in Table 1, we considered the cycloaddition between benzylazide $\mathbf{1 b}$, phenylazide $\mathbf{1 c}$ and methyl propiolate 2 (Scheme 1, Table 4). While the reaction times were dependent upon the azide, the reactant conversion was satisfactory for all the NPs. Again, the best conversion and regioselectivity were achieved in the presence of the $\mathrm{Fe}_{3} \mathrm{O}_{4}$ NPs.

Because of the close similarity of the ${ }^{1} \mathrm{H}-\mathrm{NMR}$ spectra of the isomeric cycloadducts 4 and $\mathbf{5}$, the independent synthesis of the 4-substituted 1,2,3-triazoles 4 were performed in the presence of copper (I) oxide in toluene (see Experimental Section).

Table 4. Cycloaddition between azides $\mathbf{1 b}, \mathbf{c}$ and methyl propiolate 2.

\begin{tabular}{|c|c|c|c|c|c|c|c|c|}
\hline Entry & NPs & $\mathrm{R}^{1}$ & $\begin{array}{c}w_{\mathrm{Fe}} / w_{\mathbf{1 b}, \mathbf{c}} \\
(\%)\end{array}$ & $\begin{array}{c}w_{\mathrm{M}} / w_{1 \mathbf{b}, \mathbf{c}} \\
(\% \mathbf{\%})\end{array}$ & $\begin{array}{l}\text { Time } \\
\text { (h) }\end{array}$ & $\begin{array}{l}\mathrm{T} \\
\left({ }^{\circ} \mathrm{C}\right)\end{array}$ & $\begin{array}{l}4+5 \\
(\%)\end{array}$ & 4: 5 \\
\hline 1 & - & $\mathrm{CH}_{2} \mathrm{Ph}$ & - & - & 22 & 75 & 85 & $73: 27$ \\
\hline 2 & $\mathrm{Fe}_{3} \mathrm{O}_{4}$ & $\mathrm{CH}_{2} \mathrm{Ph}$ & 48 & - & 24 & 45 & 96 & $82: 18^{a}$ \\
\hline 3 & $\mathrm{CoFe}_{2} \mathrm{O}_{4}$ & $\mathrm{CH}_{2} \mathrm{Ph}$ & 23 & $8.5(\mathrm{Co})$ & 24 & 45 & 90 & $76: 24^{2}$ \\
\hline 4 & $\mathrm{MnFe}_{2} \mathrm{O}_{4}$ & $\mathrm{CH}_{2} \mathrm{Ph}$ & 15 & $5.1(\mathrm{Mn})$ & 20 & 45 & 88 & $78: 22^{a}$ \\
\hline 5 & $\mathrm{MnO}$ & $\mathrm{CH}_{2} \mathrm{Ph}$ & - & $8.2(\mathrm{Mn})$ & 21 & 45 & 80 & $81: 19^{a}$ \\
\hline 6 & $\alpha-\mathrm{MnS}$ & $\mathrm{CH}_{2} \mathrm{Ph}$ & - & $7.1(\mathrm{Mn})$ & 22 & 45 & 84 & $78: 22^{a}$ \\
\hline 7 & - & $\mathrm{Ph}$ & - & - & 20 & 90 & 99 & $75: 25$ \\
\hline 8 & $\mathrm{Fe}_{3} \mathrm{O}_{4}$ & $\mathrm{Ph}$ & 54 & - & 8 & 45 & 99 & $82: 18^{a}$ \\
\hline 9 & $\mathrm{CoFe}_{2} \mathrm{O}_{4}$ & $\mathrm{Ph}$ & 26 & $9.6(\mathrm{Co})$ & 8 & 45 & 95 & $82: 18^{a}$ \\
\hline 10 & $\mathrm{MnFe}_{2} \mathrm{O}_{4}$ & $\mathrm{Ph}$ & 16 & $5.5(\mathrm{Mn})$ & 8 & 45 & 95 & $78: 22^{a}$ \\
\hline 11 & $\mathrm{MnO}$ & $\mathrm{Ph}$ & - & $9.1(\mathrm{Mn})$ & 8 & 45 & 92 & $74: 26^{\mathrm{a}}$ \\
\hline 12 & $\alpha-\mathrm{MnS}$ & $\mathrm{Ph}$ & - & $7.9(\mathrm{Mn})$ & 8 & 45 & 95 & $77: 23^{a}$ \\
\hline
\end{tabular}

${ }^{a}$ As determined by ${ }^{1} \mathrm{H}$ NMR analysis. 
By submitting azide 1a to the reaction with dimethylacetylenedicarboxylate 3 (DMAD), the cycloadduct 6 was obtained quantitatively in the presence of both $\mathrm{Fe}_{3} \mathrm{O}_{4}$ and $\mathrm{MnFe}_{2} \mathrm{O}_{4}$ at $20{ }^{\circ} \mathrm{C}(\mathrm{Scheme}$ 2 , Table 5). The uncatalysed cycloaddition also occurred in the same conditions requiring longer reaction times. Notwithstanding it is known that Huisgen cycloadditions usually occur at high temperature, ${ }^{58}$ this latter result should be related to the high dipolarophilic aptitude of DMAD. The obtainment of the 1,2,3triazole 6 represents a dissimilarity with respect to Sharpless' "click" azide-alkyne cycloaddition since it is well-known that it does not occur onto 1,2-disubstituted acetylenes. However, a few examples of $\mathrm{Cu}(\mathrm{I})$ complexes have been shown to catalyse the cycloaddition to internal alkynes. ${ }^{59}$
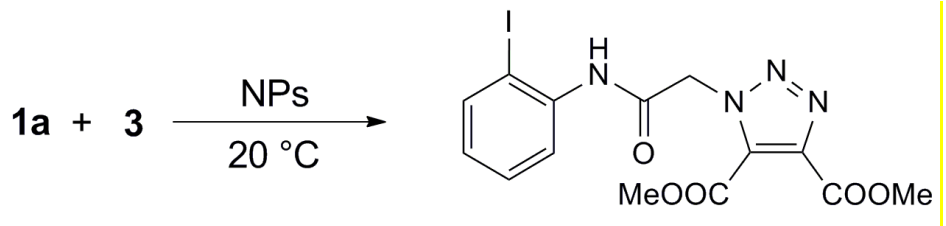

6

Scheme 2. 1,2,3-Triazole 6 obtained from the cycloaddition between azide 1a and DMAD 3 in the presence of NPS (see also Table 5)

Table 5. Cycloaddition between azide 1a and DMAD 3.

\begin{tabular}{llcclll}
\hline Entry & $\mathrm{NPs}$ & $\begin{array}{c}w_{\mathrm{Fe}} / w_{\mathbf{1 a}} \\
(\% \mathbf{\%})\end{array}$ & $\begin{array}{c}w_{\mathrm{Mn}} / w_{\mathbf{1 a}} \\
(\% \mathbf{\%})\end{array}$ & $\begin{array}{l}\text { Time } \\
(\mathrm{h})\end{array}$ & $\begin{array}{l}\mathrm{T} \\
\left({ }^{\circ} \mathrm{C}\right)\end{array}$ & $\begin{array}{l}\mathbf{6} \\
(\%)\end{array}$ \\
\hline 1 & - & - & - & 96 & 20 & 72 \\
2 & $\mathrm{Fe}_{3} \mathrm{O}_{4}$ & 5 & - & 22 & 20 & 99 \\
3 & $\mathrm{MnFe}_{2} \mathrm{O}_{4}$ & 6 & 2 & 20 & 20 & 91 \\
4 & - & - & - & 4 & 95 & 95 \\
5 & $\mathrm{Fe}_{3} \mathrm{O}_{4}$ & 5 & - & 1 & 95 & 99 \\
\hline
\end{tabular}

The recycling of the NPs was studied for the cycloaddition of $1 \mathrm{c}$ to 2 catalysed by $\mathrm{Fe}_{3} \mathrm{O}_{4} \mathrm{NPs}$. We performed two series of experiments. The first one follows a conventional protocol: the NPs were magnetically recovered, washed, and immediately dispersed in fresh solvent. In the second series, the magnetically recovered NPs were washed, dried, and weighted before dispersion in fresh solvent in order to measure the loss of NPs due to manipulation. Figure 5 shows the cycloaddition yield for 5 cycles. The isolation yield, as measured in the conventional recycling experiments, decreases with recycling and falls below $50 \%$ of the initial value at the fifth cycle. 
From the second series of experiments, we learned that the NP mass decreases after each cycle due to manipulation (see ESI, Figure S3). However, it was not possible to envisage the presence of iron in the mother solution i.e. in the cycloadducts mixtures. It is likely that the tiny amount of $\mathrm{Fe}_{3} \mathrm{O}_{4} \mathrm{NPs}\left(5.5 \mathrm{mg}_{\mathrm{Fe}}\right.$ per cycle on average, compared to $\sim 750 \mathrm{mg}$ of cycloadducts) was lost by washing of the mother solution with water followed by crystallisation of the crude triazoles. When the isolation yield is scaled by the remaining amount of NPs, it remains constant for four cycles and falls to $80 \%$ of the initial value at the fifth cycle. The recycling ability of these NPs is not striking but one should recall that they are cheap and do not present serious waste management problems being composed of biocompatible iron oxide and fatty acids so extended recycling is not as important as for precious or toxic catalysts.

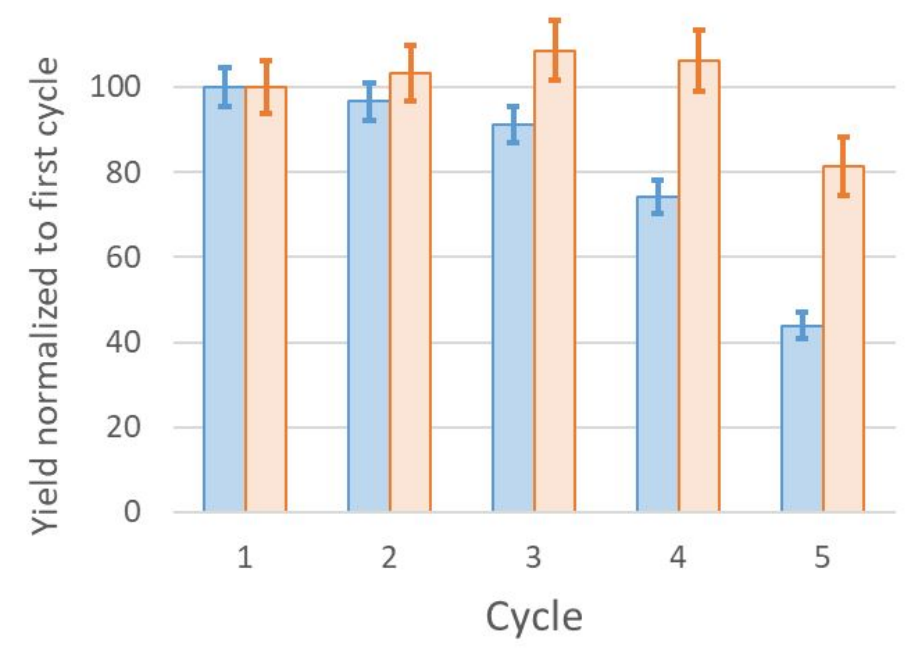

Figure 5. Catalyst recycling for the $1 \mathrm{c}+\mathbf{2}$ cycloaddition catalysed by $\mathrm{Fe}_{3} \mathrm{O}_{4} \mathrm{NPs}$. Blue: isolation yield. Orange: isolation yield scaled to the NP loss. All yields are normalized to the value at cycle 1. Error bars represent 2 standard deviations.

To better understand the fate of the catalytic NPs, we analysed $\mathrm{Fe}_{3} \mathrm{O}_{4}$ NPs after the fifth conventional run by TEM and FT-IR. The FT-IR spectra of fresh and used catalyst are similar (Figure 3), showing that NPs maintain the oleic acid coating. Note that no peaks attributable to $\mathbf{1 c}$ or $\mathbf{2}$ can be seen. The iron oxide NP core maintained the magnetite structure after the five cycloaddition runs as shown by the ED patterns in Figure 2. TEM images show that the NPs formed large agglomerates with size $>100 \mathrm{~nm}$, in which the $\mathrm{Fe}_{3} \mathrm{O}_{4}$ /oleic acid NPs maintain their individuality (Figure 1). The size of the NPs in unaffected by the use as a catalyst. Thus, in addition to NP loss by manipulation, another cause of decreased activity of the NPs is the agglomeration of the otherwise unchanged NPs that slows down the diffusion of reactants and products to and from the NP surface and lowers the number of catalytic sites available for reaction. These 
results suggest that the recycling ability of the NPs could be increased by (i) improving the magnetic separation by optimized magnetic field gradients and (ii) sonicating the dispersed NPs

The comparison of the present results with those previously obtained through an uncatalysed cycloaddition must be limited to the reaction between phenylazide 1c and methyl propiolate $\mathbf{2}$. In fact, cycloadducts $\mathbf{4 a}$ and $\mathbf{5 a}$ are novel products, while the 1,2,3-triazoles $\mathbf{4 b}$ and $\mathbf{5 b}$ arising from the reaction of benzylazide $\mathbf{1 b}$ and methyl propiolate $\mathbf{2}$ were obtained as unique regioisomers in the presence of copper(I) ${ }^{60}$ or $\mathrm{Cp} * \mathrm{RuCl}\left(\mathrm{PPh}_{3}\right)_{2}{ }^{61}$ catalysts, respectively. As described by Huisgen, ${ }^{62}$ phenylazide 1c reacted with methyl propiolate 2 in the absence of solvent for 12 days at r.t. plus $34 \mathrm{~h}$ at $60{ }^{\circ} \mathrm{C}$ yielding a mixture of 1-phenyl-4-methoxycarbonyl-1,2,3-triazole $\mathbf{4 c}$ and 5-methoxycarbonyl isomer $\mathbf{5 c}$ in $88: 12$ ratio ( $83 \%$ combined yield). In a previous report, ${ }^{63}$ we investigated the reactive behaviour of phenylazides and methyl propiolate in boiling tetrachloromethane. After $36 \mathrm{~h}$, the $\mathbf{1 c}+\mathbf{2}$ cycloaddition gave 4c : $\mathbf{5 c}=75: 25$ (>96\% overall yield). Comparison of these results with Table 4 shows that NP catalysis provides better yield and similar regioselectivity in a much shorter time and at lower temperature. Furthermore, the use of a copper(I) nanocatalyst was able to furnish selectively both the 4methoxycarbonyl-1,2,3-triazoles $\mathbf{4} \mathbf{b}^{60}$ and $\mathbf{4 c} .^{20}$ In both cases, yields $>90 \%$ were achieved in a few hours at RT.

Compared to the above mentioned Huisgen-type cycloadditions, ${ }^{58,62}$ our present results show that the catalytic effect of the studied NPs is such to increase the reaction rate without significantly enhancing the regioselectivity in favour of the 4-substituted triazoles 4 . This behaviour may be ascribed to the reversible formation of a labile azide-NP intermediate that reacts with the alkyne faster than the free azide. The intermediate arises from the interaction between the azide moiety and the uncoordinated metal ion at the NP surface, as shown in Scheme 3. This hypothesis is based on the following considerations. First, we have shown that the catalytic effect is due to the NP surface, most probably to under-coordinated metal ions, since both bulk iron oxide and iron(III) oleate and do not increase the cycloaddition rate. The lack of azide degradation, the absence of by-products, and the occurrence of the cycloaddition to a 1,2disubstitued acetylene are consistent with the formation of an azide-NP intermediate. It seems likely that organic azides ligate to surface iron ions since both complexes of $\mathrm{Fe}$ (III) with the $\mathrm{N}_{3}^{-}$anion ${ }^{64}$ and transition metal complexes with aromatic azide ligands ${ }^{65}$ are known, despite that $\mathrm{Fe}(\mathrm{III})$ complexes with organic azide ligands have not been reported (at the best of our knowledge). Ligation of the alkyne ester to surface iron ions is unlikely as Fe(III) complexes with alkynes or esters seem to be of very minor importance.

However, further investigations would be desirable to unravel the details of the mechanistic features concerned to the catalytic activity of the mentioned nanoparticles. In order to get further support to the 
proposed mechanism of the NP-catalysed azide-alkyne cycloaddition, we carried out DFT calculations that are reported in the next subsection.

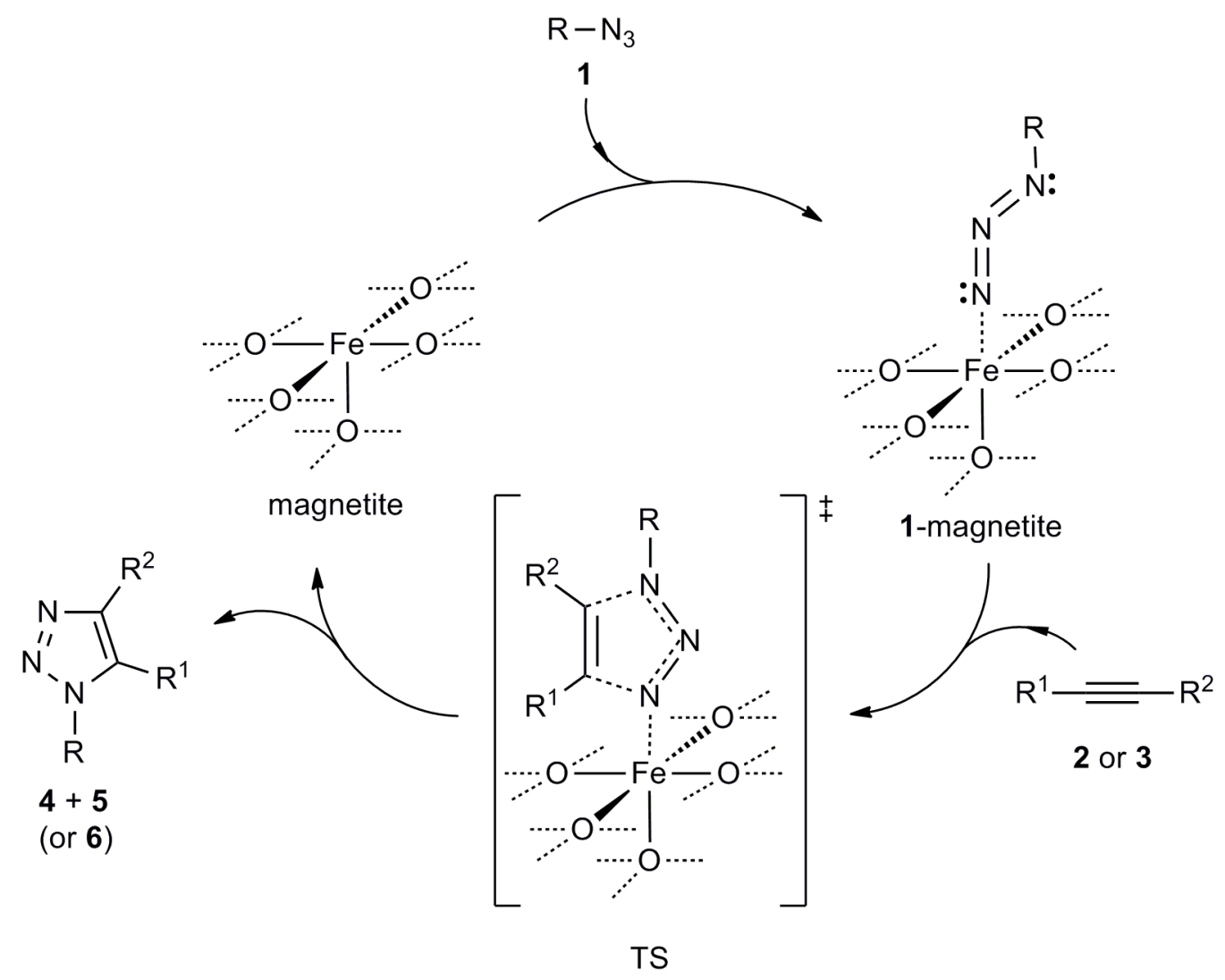

Scheme 3. Proposed catalytic cycle for the NP-catalysed cycloaddition between azide $\mathbf{1}$ and alkyne $\mathbf{2}$ in the presence of magnetite NPs. The key step is the adsorption of the azide onto an under-coordinated Fe site at the NP surface. For the sake of clarity, we pictured a single transition state structure but it is understood that both regioisomeric transition states occur. A similar cycle is thought to be effective for mixed ferrites, $\mathrm{MnO}$, and $\mathrm{MnS}$.

\subsection{Computational results}

DFT calculations were carried out to assess the plausibility of our working hypothesis that the increased reaction rate is related to the adsorption of the azide on the NP surface via the interaction between the azido group and under-coordinated surface metal ions. Theoretical computations focused on the cycloaddition of phenylazide 1c to methyl propiolate 2 catalysed by iron oxide NPs. The problem was attacked in two ways. First, we employed a periodic model where 1c is ligated to an under-coordinated iron(III) ion at the (100) surface of a magnetite $\left(\mathrm{Fe}_{3} \mathrm{O}_{4}\right)$ slab. Periodic calculations with full geometric relaxation provides a description of the electronic structure of the 1c-magnetite system allowing us to discuss the NP catalytic effect using a frontier molecular orbital (FMO) approach. Since periodic 
calculations do not allow one to locate transition states (TSs), we secondly used simple molecular models (neutral $\mathrm{Fe}(\mathrm{OH})_{3}{ }^{40}$ or $\mathrm{Fe}_{2}(\mathrm{OH})_{4}$ fragments ligated to 1c) to calculate the regioisomeric TSs of the 1c +2 reaction.

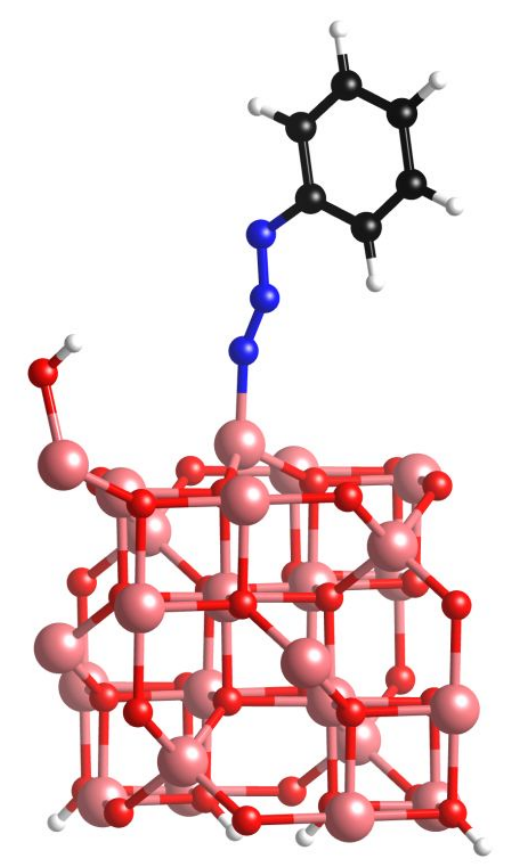

Figure 6. Minimum-energy structure of the 1c-magnetite adsorption complex. Colour code is as follows. White: hydrogen; black: carbon; blue: nitrogen; red: oxygen; pink: iron.

Figure 6 shows the unit cell of the magnetite (100) surface adopted in the periodic computations and the 1c azide molecule adsorbed in its minimum energy conformation. We are confident that the results discussed below do not significantly depend on the surface orientation.

According to the FMO approach, reactivity is enhanced when the energy gap between the highest occupied (HOMO) and the lowest unoccupied molecular orbital (LUMO) of the reactants decreases. In molecular systems, the available electronic states correspond to a set of discrete orbital energies. In periodic systems, available electronic states can be found in extended energy intervals (bands) and are collectively pictured by a continuous curve representing the density of available states (DOS). The larger the DOS in a given energy range, the larger the number of states accessible to electrons. We note here that, since magnetite is a magnetic material with a different number of spin-up and spin-down electrons, $a b$ initio computations provide two distinct sets of electronic states and hence two different DOS, one for each spin component. To get clear evidence of the energy range where the orbitals of a given atom group contribute significantly to global electronic states, we projected the DOS of 1c-magnetite onto the orbitals of azide nitrogens, phenyl carbons and the iron atom interacting with 1c. The analysis conducted below 
safely assumes that the reaction between 1c-magnetite and $\mathbf{2}$ involves electronic states with significant orbital contribution coming from the $-\mathrm{N}_{3}(\mathbf{1 c})$ and the $-\mathrm{C} \equiv \mathrm{C}-(\mathbf{2})$ moieties.

The DOS of 1c adsorbed onto the (100) ferrite surface is shown in Figure 7 along with the orbital energies of the isolated $\mathbf{2}$ and 1c molecules, while relevant HOMO - LUMO gaps have been collected in Table 6. For the isolated molecules, we have highlighted the MOs with a large contribution from the reactive moieties $-\mathrm{N}_{3}$ (blue, 1c) and $-\mathrm{C} \equiv \mathrm{C}-$ (black, 2). For the 1c-magnetite system, the contributions to the DOS from azide nitrogens (blue), phenyl carbons (grey) and the iron atom interacting with 1c (red) show where the electronic states relevant to the reaction are located. Pictures of relevant electronic states of 2, 1c, and 1c-magnetite can be found in the ESI (Figure S4).

Table 6. Computed HOMO-LUMO energy gaps (eV) for selected systems.

\begin{tabular}{lccc}
\hline System & spin component & $\Delta E[\mathrm{HOMO}(\mathbf{1 c})-$ & $\Delta E[\mathrm{HOMO}(\mathbf{2})-$ \\
& & $\mathrm{LUMO}(\mathbf{2})]$ & 4.7 \\
\hline $\mathbf{1 c}+\mathbf{2}$ (gas phase) & both & 3.2 & 3.4 \\
$\mathbf{1 c}-$ magnetite $+\mathbf{2}$ & down (minority) & 3.3 & 3.5 \\
1c-magnetite $+\mathbf{2}$ & up (majority) & 2.5 & $\mathbf{1}$ ) \\
\hline
\end{tabular}

As can be seen in Table 6, the HOMO-LUMO gaps between $1 \mathrm{c}$ and 2 are 3.2 and $4.7 \mathrm{eV}$, indicating HOMO-dipole control. Adsorption of 1c onto the magnetite surface produces marked effects on its electronic structure, which affect the HOMO-LUMO gaps (Figure 7). The overlap of azide and iron peaks in the DOS shows that the molecular states of 1c hybridize with states located on the magnetite iron atoms (see the states pictured in Figure S5 in the ESI). 


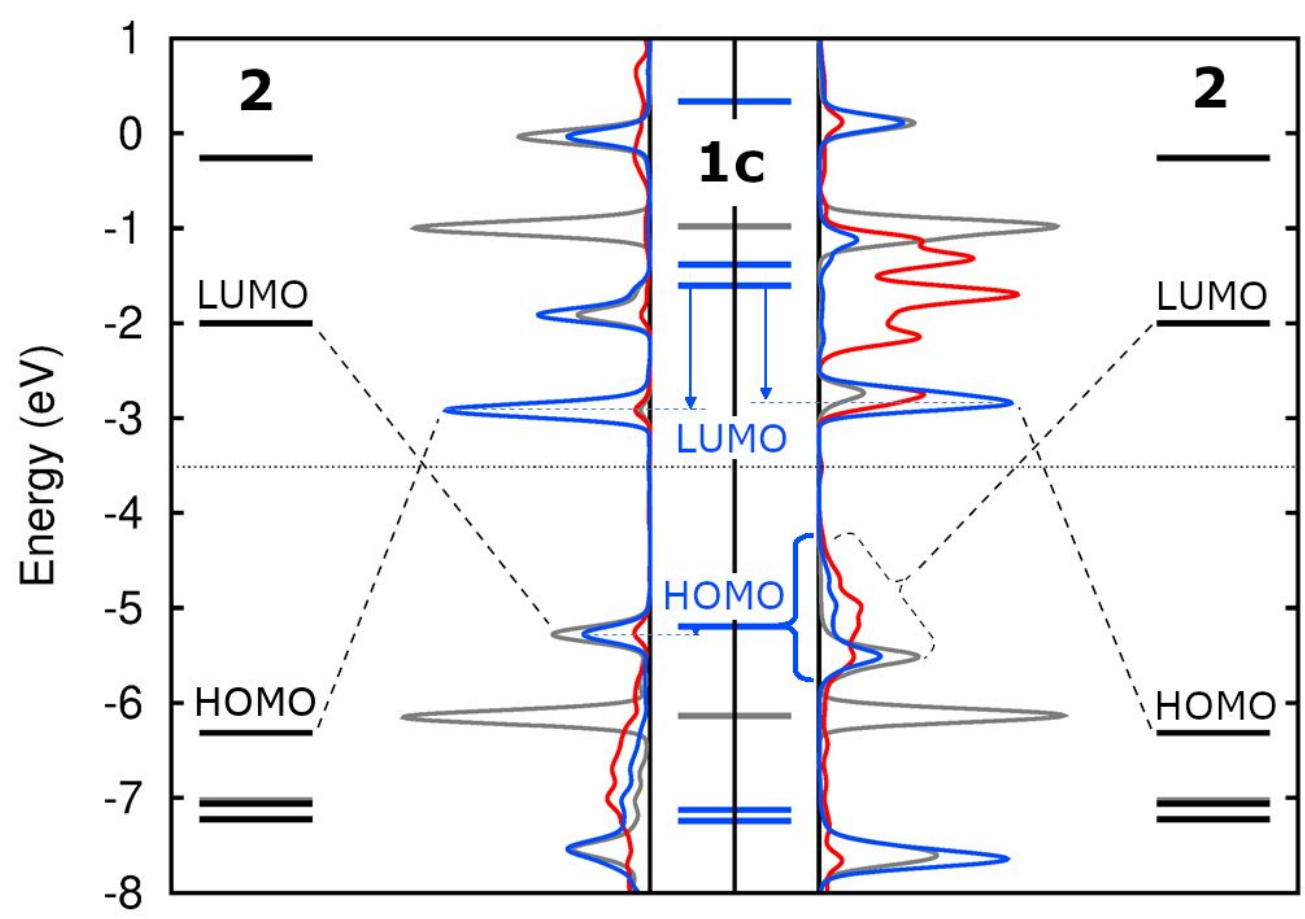

Figure 7. Electronic states of isolated 1c and the 1c-magnetite complex compared with the states of 2. The states of isolated 1c (middle) and 2 (left and right ends) are represented as thick lines. The states of isolated 1c having large contribution from the $-\mathrm{N}_{3}$ moiety are blue and the states of having large contribution from the $-\mathrm{C} \equiv \mathrm{C}-$ moiety are black. The density of states (DOS) of spin down (left panel) and spin up (right panel) electrons of the magnetite-1c complex are portrayed as continuous curves. Contributions from different moieties are color coded as follows. Blue: azide nitrogens, grey: phenyl carbons, red: iron atom interacting with 1c. The Fermi level is displayed as a dotted horizontal line (electronic states below the Fermi level are occupied, states above it are empty). The energy shift of the 1c HOMO and LUMO upon adsorption are indicated by blue arrows. Relevant HOMO-LUMO interactions are highlighted with dashed lines.

As concerns the spin-down electronic states (left panel), we note that the peak corresponding to the $\operatorname{HOMO}(\mathbf{1 c})$ state slightly mixes with Fe orbitals, and its energy slightly lowers with respect to the gasphase $(-0.1 \mathrm{eV})$. A little hybridization among Fe and $\mathrm{N}$ states occurs also for the LUMO(1c) peak, leading to a much larger energy shift of about $-1.3 \mathrm{eV}$. Consistently, upon adsorption of 1c onto magnetite, the $\operatorname{HOMO}(\mathbf{1 c})$ - $\operatorname{LUMO}(\mathbf{2})$ gap changes slightly with respect to the isolated molecules (see Table 6), while the $\operatorname{HOMO}(2)$ - LUMO(1c) drops from 4.7 to $3.4 \mathrm{eV}$.

The hybridization of 1c frontier orbitals with spin-up magnetite states is stronger and more intriguing. The LUMO(1c) orbital hybridizes with states at the surface of magnetite, giving rise to a peak at about - 
$2.8 \mathrm{eV}$. The HOMO(1c) strongly mixes with magnetite states giving rise to a broad band of HOMO-like azide-iron states ranging from $-5.5 \mathrm{eV}$ to about $-4.5 \mathrm{eV}$. The spin-up HOMO-LUMO energy gaps between 1c-magnetite and $\mathbf{2}$ drop to $2.5[\mathrm{HOMO}(\mathbf{1 c})-\operatorname{LUMO}(\mathbf{2})]$ and $3.5 \mathrm{eV}[\mathrm{HOMO}(\mathbf{2})-\mathrm{LUMO}(\mathbf{1 c})]$, values much smaller than those of the $\mathbf{1 c}+\mathbf{2}$ reaction. These spin-up 1c-magnetite hybrid electronic states, which contain large contributions from the $-\mathrm{N}_{3}$ moiety, provide a faster HOMO-dipole controlled reactivity channel.

The computational results on the periodic model thus suggest that the adsorption of azide 1c on the magnetite surface is likely to increase the cycloaddition rate because of lower energy gaps for both spindown (azide-like orbitals) and spin-up (hybrid orbitals) electrons. It is less clear what effect adsorption might have on the regioselectivity since HOMO-dipole control is weaker for magnetite-adsorbed $1 \mathbf{c}(\delta \Delta E$ $=1.1$ and $1.0 \mathrm{eV})$ than for isolated $1 \mathrm{c}(\delta \Delta E=1.5 \mathrm{eV})$.

To gain more insight, we then turned to the investigation of the relevant TSs in the above delineated simple molecular model. The geometry of the regioisomeric TSs of $\mathbf{1 c}-\mathrm{Fe}(\mathrm{OH})_{3}+\mathbf{2}$ and $\mathbf{1 c}-\mathrm{Fe}_{2}(\mathrm{OH})_{4}+\mathbf{2}$ optimized at the OPBE/LANL2/LANL2DZ level are shown in Figure 8. (The 1c $+\mathbf{2}$ TSs and the 1c$\mathrm{Fe}(\mathrm{OH})_{3}$ and $\mathbf{1 c}-\mathrm{Fe}_{2}(\mathrm{OH})_{4}$ adducts can be found in the ESI, Figure S6). 

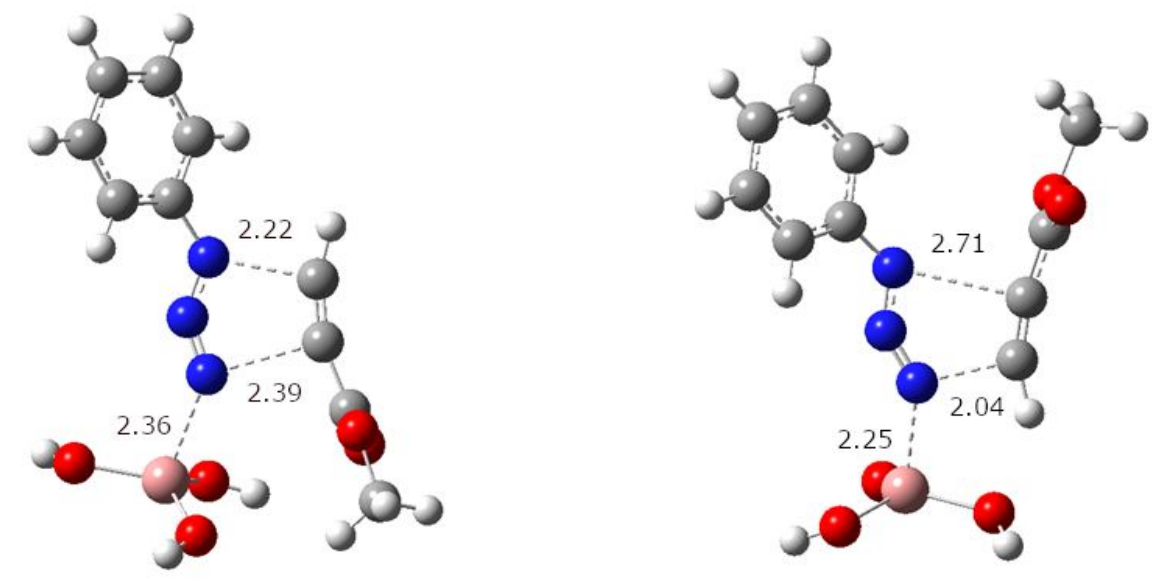

$\mathrm{TS} \mathbf{1 c}-\mathrm{Fe}(\mathrm{OH})_{3}+\mathbf{2} \rightarrow \mathbf{4}$

TS $\mathbf{1 c}-\mathrm{Fe}(\mathrm{OH})_{3}+\mathbf{2} \rightarrow \mathbf{5}$
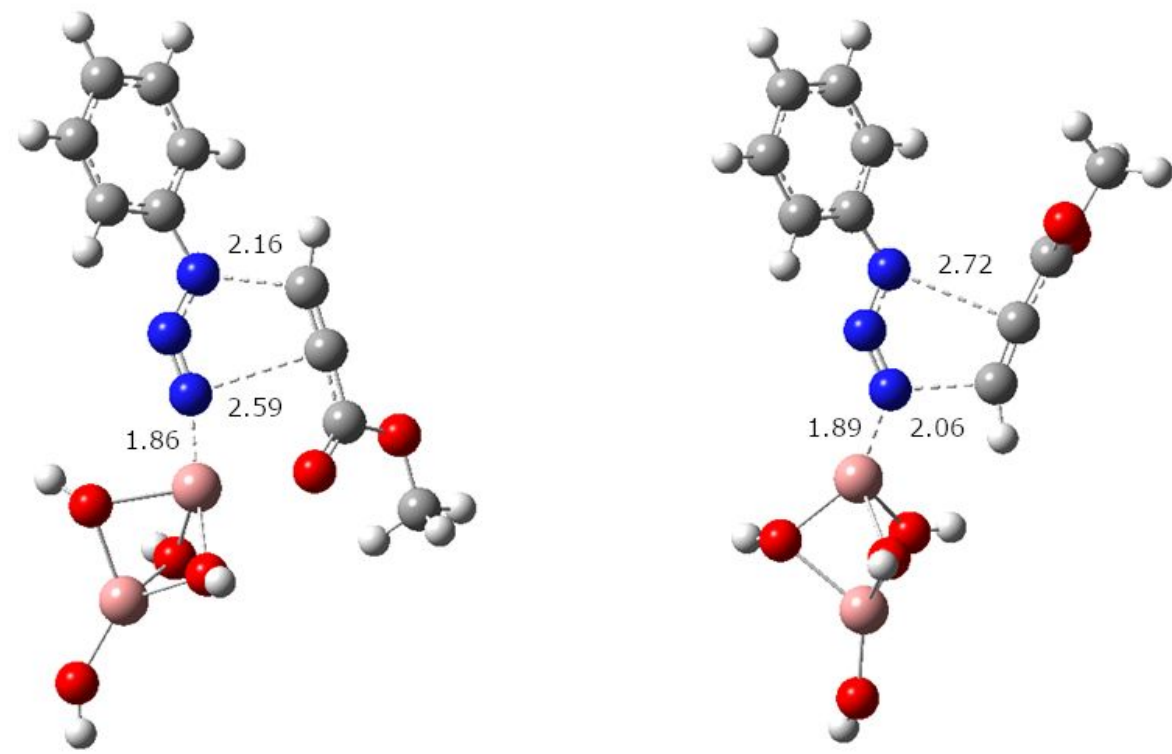

TS $\mathbf{1 c}-\mathrm{Fe}_{2}(\mathrm{OH})_{4}+\mathbf{2} \rightarrow \mathbf{4}$

TS $\mathbf{1 c}-\mathrm{Fe}_{2}(\mathrm{OH})_{4}+\mathbf{2} \rightarrow \mathbf{5}$

Figure 8. Structure of the regioisomeric transition states of the $\mathbf{1 c}-\mathrm{Fe}(\mathrm{OH})_{3}+\mathbf{2}$ and $\mathbf{1 c}-\mathrm{Fe}_{2}(\mathrm{OH})_{4}+\mathbf{2}$ reactions. Relevant distances are given in angstrom. Colour code is as follows. White: hydrogen; grey: carbon; blue: nitrogen; red: oxygen; pink: iron.

The presence of the Fe-O clusters does not affect much the TS structures. With respect to the $\mathbf{1 c}+\mathbf{2}$ case, the TS leading to $\mathbf{4}$ is more symmetrical than that leading to $\mathbf{5}$ and the length of the forming bonds changes by less than $0.1 \AA$, except for one case. The activation energy $E^{\ddagger}=E(\mathrm{TS})-E(\mathbf{1 c})-E(\mathbf{2})$ for the cycloadditions between 2 and both ligated and non-ligated 1c leading to the $\mathbf{4}$ and $\mathbf{5}$ cycloadduct are collected in Table 7. The ligation of 1c to Fe-O clusters decreases the TS energy of both regioisomeric pathways leading to a significant increase of the reaction rate, in agreement with experiments. However, 
the data are inconsistent with respect to regioselectivity. One model favours the $\mathbf{4}$ cycloadduct whereas the other one favours the $\mathbf{5}$ cycloadduct. This is not unexpected due to (i) the simplistic models employed and (ii) the high accuracy $(<1 \mathrm{kcal} / \mathrm{mol})$ needed to predict the regioselectivity. The computational results based on the molecular model systems support the FMO analysis of the periodic model calculations. We can thus conclude that DFT calculations support the hypothesis that the observed catalytic effect is due to the coordination of $\mathbf{1} \mathbf{c}$ to an under-coordinated iron ion at the NP surface.

Table 7. DFT (OPBE/LANL2/LANL2DZ) activation energy $E^{\ddagger}(\mathrm{kcal} / \mathrm{mol})$ for the 4- and 5-regioisomers of the cycloaddition between 2 and both ligated and unligated $\mathbf{1 c}$.

\begin{tabular}{lcc}
\hline & $\mathbf{4}$ & $\mathbf{5}$ \\
\hline $\mathbf{1 c}$ & 17.2 & 17.1 \\
$\mathbf{1 c}-\mathrm{Fe}(\mathrm{OH})_{3}$ & 15.0 & 13.1 \\
$\mathbf{1 c}-\mathrm{Fe}_{2}(\mathrm{OH})_{4}$ & 10.1 & 16.1 \\
\hline
\end{tabular}

\section{Conclusions}

A novel protocol for the catalysed azide-alkyne cycloaddition has been developed, which involves upon Earth-abundant, first-row transition metal oxides and sulfide nanocatalysts. These solvent-dispersible, inexpensive magnetic nanoparticles allowed milder reaction conditions and better product yields compared to the corresponding examples of the classic Huisgen reaction. The regioselectivity of the catalysed cycloaddition towards the 4-cycloadduct was to some extent improved with respect to the thermal process, and the reaction to 1,2-disubstituted acetylenes was proved to be feasible. Experimental and computational results support the hypothesis that the reaction rate increase is due to enhanced reactivity of the adduct between the azide and an under-coordinated iron ion at the surface of the NPs with respect to the free azide. 


\section{Conflicts of interest}

There are no conflicts of interest to declare.

Acknowledgements. G. M. was financially supported by the Department of Chemistry of the Università degli Studi di Milano (PSR2015-1716FDEMA_09).

\section{References}

1. D. Wang, D. Astruc, Chem. Soc. Rev., 2017, 46, 816-854.

2. S. Shylesh, V. Schünemann, W. R. Thiel, Angew. Chem. Int. Ed., 2010, 49, 3428-3459.

3. A. Padwa, in Comprehensive Organic Synthesis, Vol. 4, (Ed. B. M. Trost, I. Fleming and M. F. Semmelhack), Pergamon Press, Oxford, 1991, pp. 1069-1109.

4. A. Michael, J. Prakt. Chem., 1893, 48, 94-95.

5. R. Huisgen, Proc. Chem. Soc., 1961, 357-396.

6. R. Huisgen, Angew. Chem. Int. Ed. Engl., 1963, 2, 565-598.

7. R. Huisgen, Angew. Chem., Int. Ed. Engl., 1963, 2, 633-696.

8. C. W. Tornøe, C. Christensen, M. Meldal, J. Org. Chem., 2002, 67, 3057-3064.

9. V. V. Rostovtsev, L. G. Green, V. V. Fokin, K. B. Sharpless, Angew. Chem., Int. Ed., 2002, 41, 2596-2599.

10. B. C. Boren, S. Narayan, L. K. Rasmussen, L. Zhang, H. Zhao, Z. Lin, G. Jia, V. V. Fokin, J. Am. Chem. Soc., 2008, 130, 8923-8930.

11. L. K. Rasmussen, B. C. Boren, V. V. Fokin, Org. Lett., 2007, 9, 5337-5339.

12. J. R. Johansson, T. Beke-Somfai, A. Said Stålsmeden, N. Kann, Chem. Rev., 2016, 116, 1472614768.

13. W. Song, N. Zheng, Org. Lett., 2017, 19, 6200-6203

14. W. G. Kim, M. E. Kang, J. B. Lee, M. H. Jeon, S. Lee, J. Lee, B. Choi, P. M. S. D. Cal, S. Kang, J.-M. Kee, G. J. L. Bernardes, J.-U. Rohde, W. Choe, S. Y. Hong, J. Am. Chem. Soc., 2017, 139, 12121-12124.

15. S. Bräse, C. Gil, K. Knepper, V. Zimmermann, Angew. Chem. Int. Ed., 2005, 44, 5188-5240.

16. Organic Azides: Syntheses and Applications, (Ed. S. Bräse, K. Banert), John Wiley \& Sons, Ltd., Chichester, 2010, pp. 389-490.

17. S. Pålhagen, R. Canger, O. Henriksen, J. A. van Parys, M.-E. Rivière, M. A. Karolchyk, Epilepsy Res., 2001, 43, 115-124. 
18. J. Diot, M. I. García-Moreno, S. G. Gouin, C. Ortiz Mellet, K. Haupt, J. Kovensky, Org. Biomol. Chem., 2009, 7, 357-363.

19. J. M. Aizpurua, R. M. Fratila, Z. Monasterio, N. Perez-Esnaola, E. Andreieff, A. Irastorza, M. Sagartzazu-Aizpurua, New J. Chem., 2014, 38, 474- 480.

20. G. Molteni, C. L. Bianchi, G. Marinoni, N. Santo, A. Ponti, New J. Chem., 2006, 30, 1137-1139.

21. T. Jin, M. Yan, Y. Yamamoto, ChemCatChem., 2012, 4, 1217-1229.

22. F. Alonso, Y. Moglie, G. Radivoy, Acc. Chem. Res., 2015, 48, 2516-2528.

23. M. B. Gawande, A. Goswami, F.-X. Felpin, T. Asefa, X. Huang, R. Silva, X. Zou, R. Zboril, R. S. Varma, Chem. Rev., 2016, 116, 3722-3811.

24. M. Gholinejad, N. Jeddi, ACS Sustainable Chem. Eng., 2014, 2, 2658-2665.

25. S. Kaur, V. Bhalla, M. Kumar, Chem. Commun., 2015, 51, 526-529.

26. R. Hudson, C.-J. Li, A. Moores, Green Chem., 2012, 14, 622-624.

27. Z. Zhang, C. Dong, C. Yang, D. Hu, J. Long, L. Wang, H. Li,Y. Chen, D. Kong, Adv. Synth. Catal. 2010, 352, 1600-1604.

28. F. Chahdoura, C. Pradel, M. Gómez, ChemCatChem, 2014, 6, 2929-2936.

29. H. Woo, H. Kang, A. Kim, S. Jang, J. C. Park, J. C.; S. Park, B.-S. Kim, H. Song, K. H. Park, Molecules, 2012, 17, 13235-13252.

30. S. Ishikawa, R. Hudson, A. Moores, C.-J. Li, Heterocycles, 2012, 86, 1023-1030.

31. B. Kumar, K. H. V. Reddy, B. Madhav, K. Ramesh, Y. V. D. Nageswar, Tetrahedron Lett., 2012, 53, 4595-4599.

32. M. R. Decan, S. Impellizzeri, M. L. Marin, J. C. Scaiano, Nat. Commun., 2014, 5, 4612.

33. J. E. Hein, V. V. Fokin, Chem. Soc. Rev., 2010, 39, 1302-1315.

34. A. M. Ferretti, A. Ponti, G. Molteni, Tetrahedron Lett., 2015, 56, 5727-5730.

35. R. Hudson, Y. Feng, R. S. Varma, A. Moores, Green Chem., 2014, 16, 4493-4505.

36. C. Della Pina, M. Rossi, A. M. Ferretti, A. Ponti, M. Lo Faro, E. Falletta, Synthetic Met., 2012, 162, 2250-2258.

37. A. Gervasini, C. Messi, A. Ponti, S. Cenedese, N. Ravasio, J. Phys. Chem. C, 2008, 112, 46354642.

38. A. Gervasini, C. Messi, P. Carniti, A. Ponti, N. Ravasio, F. Zaccheria, J. Catal., 2009, 262, 224234.

39. M. Tejeda-Serrano, J. R. Cabrero-Antonino, V. Mainar-Ruiz, M. López-Haro, J. C. HernándezGarrido, J. J. Calvino, A. Leyva-Pérez, A. Corma, ACS Catal., 2017, 7, 3721-3729.

40. G. Molteni, A. M. Ferretti, S. Mondini, A. Ponti, J. Nanopart. Res., 2018, 20, 79. 
41. a) L. Menini, M. C. Pereira, L. A. Parreira, J. D. Fabris, E. V. Gusevskaya, J. Catal., 2008, 254, 355-364; b) B. Sahoo, S. Kumar Sahu, S. Nayak, D. Dharaa, P. Pramanik, Catal. Sci. Technol., 2012, 2, 1367-1374.

42. M. Kazemi, M. Ghobadi, A. Mirzaie, Nanotech. Rev., 2017, 7, 43-68.

43. P. Calcagnile, D. Fragouli, I. S. Bayer, G. C. Anyfantis, L. Martiradonna, P. D. Cozzoli, R. Cingolani, A. Athanassiou, ACS Nano, 2012, 6, 5413-5419.

44. H. Zhu, S. Zhang, Y. -X. Huang, L. Wu, S. Sun, Nano Lett., 2013, 13, 2947-2951.

45. E. Capetti, A. M. Ferretti, V. Dal Santo, A. Ponti, Beilstein J. Nanotechnol., 2015, 6, 2319-2329.

46. J. M. Soler, E. Artacho, J. D. Gale, A. Garcìa, J. Junquera, P. Ordejòn, D. Sànchez-Portal, J. Phys. Cond. Matt., 2002, 14, 2745-2779.

47. H. Liu, C. Di Valentin, J. Phys. Chem. C, 2017, 121, 25736-25742.

48. M. Swart, J. Chem. Theory Comput. 2008, 4, 2057-2066.

49. Gaussian 09, revision C.01, M. J. Frisch, G. W. Trucks, H. B. Schlegel, G. E. Scuseria, M. A. Robb, J. R. Cheeseman, G. Scalmani, V. Barone, B. Mennucci, G. A. Petersson, H. Nakatsuji, M. Caricato, X. Li, H. P. Hratchian, A. F. Izmaylov, J. Bloino, G. Zheng, J. L. Sonnenberg, M. Hada, M. Ehara, K. Toyota, R. Fukuda, J. Hasegawa, M. Ishida, T. Nakajima, Y. Honda, O. Kitao, H. Nakai, T. Vreven, J. A. Montgomery, Jr., J. E. Peralta, F. Ogliaro, M. Bearpark, J. J. Heyd, E. Brothers, K. N. Kudin, V. N. Staroverov, R. Kobayashi, J. Normand, K. Raghavachari, A. Rendell, J. C. Burant, S. S. Iyengar, J. Tomasi, M. Cossi, N. Rega, J. M. Millam, M. Klene, J. E. Knox, J. B. Cross, V. Bakken, C. Adamo, J. Jaramillo, R. Gomperts, R. E. Stratmann, O. Yazyev, A. J. Austin, R. Cammi, C. Pomelli, J. W. Ochterski, R. L. Martin, K. Morokuma, V. G. Zakrzewski, G. A. Voth, P. Salvador, J. J. Dannenberg, S. Dapprich, A. D. Daniels, Ö. Farkas, J. B. Foresman, J. V. Ortiz, J. Cioslowski, D. J. Fox, Gaussian, Inc., Wallingford, CT, 2010.

50. S. Mondini, M. Leonzino, C. Drago, A. M. Ferretti, S. Usseglio, D. Maggioni, P. Tornese, B. Chini, A. Ponti, Langmuir, 2015, 31, 7381-7390.

51. S. Mondini, A. M. Ferretti, A. Puglisi, A. Ponti, Nanoscale, 2012, 4, 5356-5372. Pebbles is freely available from the authors, http://pebbles.istm.cnr.it.

52. A. M. Smith, K. A. Johnston, S. E. Crawford, L. E. Marbella, J. E. Millstone, Analyst, 2017, 142, 11-29.

53. W. Lwowski in 1,3-Dipolar Cycloaddition Chemistry, Vol. 1, (Ed. A. Padwa), Wiley-Interscience, New York, 1984, pp. 559-652.

54. C.-K. Sha, A. K. Mohanakrishnan in Synthetic Applications of 1,3-Dipolar Cycloaddition Chemistry Toward Heterocycles and Natural Products, Vol. 59 (Eds. A. Padwa, W. H. Pearson) John Wiley \& Sons, Inc., New York, 2002, pp. 623-679. 
55. G. Molteni, Heterocycles, 2013, 87, 1765-1773.

56. (a) Z. Li, T. S. Seoa, J. Ju, Tetrahedron Lett. 2004, 45, 3143-3146; (b) Z.-X.Wang, H.-L. Qin, Chem. Commun. 2003, 2450-2451.

57. S. R. Kale, S. S. Kahandal, M. B. Gawande, R. V. Jayaram, RSC Adv., 2013, 3, 8184-8192.

58. R. Huisgen, R. Grashey, M. Seifeld, W. Wallbillich, H. Knupfer, R. Schmidt, Ann. Chem., 1962, 653, $105-113$.

59. (a) S. Díez-González, A. Correa, L. Cavallo, S. P. Nolan, Chem. Eur. J., 2006, 12, 7558-7564; (b) N. Candelon, D. Lastécouères, A. K. Diallo, J. Ruiz Aranzaes, D. Astruc, J.-M. Vincent, Chem. Commun., 2008, 741-743; (c) S. C. Sau, S. R. Roy, T. K. Sen, D. Mullangi, S. K. Mandal, Adv. Synth. Catal., 2013, 355, 2982-2991.

60. H. A. Orgueira, D. Fokas, Y. Isome, P. C.-M. Chan, C. M. Baldino Tetrahedron Lett. 2005, 46, 2911-2914.

61. T. Farooq, L. K. Sydnes, K. W. Tornroos, B. E. Haug Synth. 2012, 44, 2070-2078.

62. R. Huisgen, R. Knorr, L. Moebius, G. Szeimies, G. Chem. Ber. 1965, 98, 4014-4021.

63. G. Molteni, A. Ponti Chem. Eur. J. 2003, 9, 2770-2774.

64. N. Wiberg, E. Wiberg, A. F. Holleman Anorganische Chemie, De Gruyter, Berlin, 2016, 103rd ed., Band 2, Teil C, Kapitel XXIX, p. 1953.

65. S. Cenini, E. Gallo, A. Caselli, F. Ragaini, S. Fantauzzi, C. Piangiolino, Coord. Chem. Rev., 2006, 250, 1234-1253. 